\title{
Gene duplication, loss and selection in the evolution of saxitoxin biosynthesis in alveolates
}

\author{
Shauna A. Murray ${ }^{\mathrm{a}, \mathrm{b}, *}$, Rutuja Diwan ${ }^{\mathrm{a}, \mathrm{b}}$, Russell J.S. Orr ${ }^{\mathrm{c}}$, Gurjeet S. Kohli ${ }^{\mathrm{a}}$, Uwe John ${ }^{\mathrm{d}}$ \\ a Plant Functional Biology and Climate Change Cluster, University of Technology Sydney, NSW 2007, Australia \\ bydney Institute of Marine Science, Chowder Bay Rd, Mosman, NSW, Australia \\ ' Section for Genetics and Evolutionary Biology, Department of Biosciences, University of Oslo, Norway \\ ${ }^{\mathrm{d}}$ Section Ecological Chemistry, Alfred-Wegener-Institut, Helmholtz-Zentrum für Polar- und Meeresforschung, Bremerhaven, Germany
}

\section{A R T I C L E I N F O}

\section{Article history:}

Received 9 March 2015

Revised 1 June 2015

Accepted 25 June 2015

Available online 30 June 2015

\section{Keywords:}

Alexandrium

Saxitoxin

sxtA

sxtG

Paralytic shellfish poisoning

Dinoflagellate

\begin{abstract}
A B S T R A C T
A group of marine dinoflagellates (Alveolata, Eukaryota), consisting of $\sim 10$ species of the genus Alexandrium, Gymnodinium catenatum and Pyrodinium bahamense, produce the toxin saxitoxin and its analogues (STX), which can accumulate in shellfish, leading to ecosystem and human health impacts. The genes, sxt, putatively involved in STX biosynthesis, have recently been identified, however, the evolution of these genes within dinoflagellates is not clear. There are two reasons for this: uncertainty over the phylogeny of dinoflagellates; and that the sxt genes of many species of Alexandrium and other dinoflagellate genera are not known. Here, we determined the phylogeny of STX-producing and other dinoflagellates based on a concatenated eight-gene alignment. We determined the presence, diversity and phylogeny of sxtA, domains A1 and A4 and sxtG in 52 strains of Alexandrium, and a further 43 species of dinoflagellates and thirteen other alveolates. We confirmed the presence and high sequence conservation of sxtA, domain A4, in 40 strains (35 Alexandrium, 1 Pyrodinium, 4 Gymnodinium) of 8 species of STX-producing dinoflagellates, and absence from non-producing species. We found three paralogs of $s x t A$, domain A1, and a widespread distribution of sxtA1 in non-STX producing dinoflagellates, indicating duplication events in the evolution of this gene. One paralog, clade 2, of sxtA1 may be particularly related to STX biosynthesis. Similarly, sxtG appears to be generally restricted to STX-producing species, while three amidinotransferase gene paralogs were found in dinoflagellates. We investigated the role of positive (diversifying) selection following duplication in sxtA1 and sxtG, and found negative selection in clades of sxtG and sxtA1, clade 2, suggesting they were functionally constrained. Significant episodic diversifying selection was found in some strains in clade 3 of sxtA1, a clade that may not be involved in STX biosynthesis, indicating pressure for diversification of function.
\end{abstract}

(c) 2015 Elsevier Inc. All rights reserved.

\section{Introduction}

Secondary metabolites, such as toxins, can act as important models for the study of evolutionary processes, as they often consist of a measurable phenotype with known ecological impacts, produced by a specific group of genes (Fischbach et al., 2008). Processes such as gene duplication, selection and lateral transfer have been found to play a role in the evolution of ecologically significant traits in protists and in cyanobacteria (Murray et al., 2011b; Slamovits and Keeling, 2008; Waller et al., 2006). Saxitoxin and its analogs (STXs), one such secondary metabolite,

\footnotetext{
This paper was edited by the Associate Editor Dr. J.B. Dacks.

* Corresponding author at: Plant Functional Biology and Climate Change Cluster, University of Technology Sydney, NSW 2007, Australia. Fax: +61 295144079

E-mail address: Shauna.Murray@uts.edu.au (S.A. Murray).
}

are alkaloid compounds with major impacts on marine environments, as they can accumulate in organisms including crustaceans, molluscs, echinoderms, cephalopods, fish, turtles, marine mammals and birds (Llewellyn et al., 2006). As they can reach high concentrations in commercial shellfish species, they have major economic impacts on aquaculture industries worldwide. STXs are produced by freshwater prokaryotic cyanobacteria and a group of marine eukaryotic protists. The genes putatively involved in STX biosynthesis (sxt), involving $\sim 30$ biosynthetic steps, are now known from $\sim 6$ cyanobacterial genera (Kellmann et al., 2008; Mihali et al., 2009, 2011; Moustafa et al., 2009; Stucken et al., 2010).

Putative genes involved in the biosynthesis of STX in dinoflagellates have been found, despite the large genome sizes ( 1-100 Gb) of dinoflagellates hampering research (Stüken et al., 2011; Murray et al., 2011a; Hii et al., 2012; Hackett et al., 2013; Orr et al., 2013; 
Suikkanen et al., 2013). They have molecular genetic characteristics typical of dinoflagellates: a conserved 22 bp spliced leader sequence at the 5' end of the transcribed mRNA; eukaryotic poly A tails; a GC content of $62-69 \%$, similar to that reported for Alexandrium genomes, compared to $43 \%$ for cyanobacterial sxtA genes; dinoflagellate-related signal peptides; and a high genomic copy number of $\sim 10^{2}$ copies cell $^{-1}$, a feature typical of dinoflagellates (Stüken et al., 2011; Murray et al., 2011a; Orr et al., 2013). A complement of 14 'core' genes ( $s x t A-s x t I, s x t P-s x t R$, sxtS, and sxtU) is common between the $s x t$ clusters of cyanobacterial STX-producing strains (Murray et al., 2011b), of which eight ( $s x t A, s x t B, s x t D, s x t G, s x t H$ or $s x t T, s x t I, s x t S$, and $s x t U$ ) may be directly implicated in STX synthesis (Kellmann et al., 2008). In cyanobacteria, the gene cluster appears to have an ancient origin, and both gene duplication and positive selection have played a role in its evolution (Murray et al., 2011b). Homologs of all genes putatively necessary for STX biosynthesis have been found in dinoflagellates, in the species Alexandrium fundyense, A. minutum, Gymnodinium catenatum and Pyrodinium bahamense (Stüken et al., 2011; Hackett et al., 2013).

Dinoflagellate producers of STX that have been studied possess the genes sxtA, putatively the initial gene in the STX synthesis pathway (Stüken et al., 2011), and the second gene sxtG (Orr et al., 2013). sxtA has four catalytic domains, with predicted activities similar to a SAM-dependent methyltransferase (sxtA1), GCN-5 related $\mathrm{N}$-acetyltransferase (sxtA2), acyl carrier protein (sxtA3) and an amidinotransferase (sxtA4) (Kellmann et al., 2008). sxtA in dinoflagellates shows two isoforms: one of which comprises four domains, sxtA1-sxtA4, while the other one encompasses only the domains sxtA1-sxtA3 (Stüken et al., 2011), and may represent a duplicated, paralogs copy of sxtA1. The domain sxtA4 appears to be necessary for STX biosynthesis, and therefore it is likely that only the isoform with this domain is active in catalysing STX biosynthesis (Murray et al., 2011a). Part or all of sxtA appears to be absent from dinoflagellate genera and families that cannot produce STX (Stüken et al., 2011; Orr et al., 2013; Murray et al., 2014; John et al., 2014). Strains of Alexandrium ostenfeldii, which do not produce STX appear to lack the domain sxtA4, while those that can produce STX have this domain (Suikkanen et al., 2013). sxtG was present in all STX-producing dinoflagellates, however it was also present in three other species within the genus Alexandrium (Orr et al., 2013).

Only limited information is available regarding the expression and function of sxtA copies (Perini et al., 2014; Zhang et al., 2014). It appears that $s x t A$ may not be strongly regulated at the transcriptional level in $A$. minutum, as toxin quantities were not well correlated with transcript abundance (Perini et al., 2014). Nevertheless, sxt $A$ was found to be significantly down regulated in a non-toxic mutant strain of A. pacificum (Zhang et al., 2014). There are several environmental factors that appear to influence the amount of STX found in the cell (reviewed in Murray et al., 2015). Certain growth phases have been correlated with higher rates of cellular toxin quota, including mid-exponential growth phase (Cembella and Destombe, 1996), or stationary phase (Parkhill and Cembella, 1999, Lim and Ogata, 2005). The cellular toxin quota appears to increase upon phosphorus limitation and decrease upon nitrogen limitation (van de Waal et al., 2014). One factor that has been found to lead to a several fold increase in cellular toxin quota is the presence of copepods and their waterborne cues (Selander et al., 2006; Wohlrab et al., 2010; Yang et al., 2011).

Almost all species of dinoflagellates that produce STX belong to the genus Alexandrium, of which $\sim 32$ species have been described, and are present worldwide in comparable habitats (Balech, 1995; Anderson et al., 2012; Farrell et al., 2013). In order to determine the evolution of sxt within dinoflagellates, a resolved phylogeny of the group, including the genus Alexandrium and closely related
Pyrodinium bahamense is necessary. Alexandrium has often appeared to form a monophyletic clade in phylogenetic analyses based on regions of the ribosomal DNA array, with a selected outgroup (John et al., 2003; Leaw et al., 2005; Orr et al., 2011; Anderson et al., 2012). Questions remain about the evolution of Alexandrium, as different studies have shown that the most basal clade is either: A. taylori (John et al., 2003; Rogers et al., 2006), A. leei (Leaw et al., 2005), a clade composed of the species A. satoanum, A. monilatum, A. taylori, A. hiranoi, A. pseudogonyaulax (Murray et al., 2014), and a clade including most of those species and A. leei (Anderson et al., 2012), or a clade including A. minutum, A. tamutum and A. ostenfeldii (Orr et al., 2011). A recent phylogeny of the group with a comprehensive species coverage, based on a concatenated alignment of the three rRNA regions, found that clades within Alexandrium were generally not well supported (Murray et al., 2014). The closest sister group to Alexandrium is not yet clear, as most studies of dinoflagellates have either focused on only Alexandrium with few outgroups; or covered all dinoflagellates, with only few Alexandrium species. In order to determine a resolved phylogeny of the genus, alignments of larger numbers of concatenated genes are necessary, and this has been shown to offer more resolution also for other dinoflagellate groups (Orr et al., 2012).

Many microbial eukaryotes appear to have genomes that are to some extent mosaic, with a significant number of genes laterally acquired, from organisms such as cyanobacteria, proteobacteria, and euglenoids (Keeling and Palmer, 2008; Waller et al., 2006; Wisecaver and Hackett, 2014). The genes sxtA and sxtG appear likely to have been acquired via an ancient transfer from a prokaryote into a dinoflagellate ancestor (Stüken et al., 2011; Orr et al., 2013). However, the extent to which lateral transfers have occurred between dinoflagellates species is not yet clear. Few species of Alexandrium have been examined for the presence of sxtA, and representatives of only some dinoflagellate families have been investigated using deep sequencing techniques. Similarly, non-dinoflagellate alveolates have not been screened for the presence of these genes. The potential role of gene duplication in the evolution of this domain is not known. The aim of this study was to examine the potential roles of horizontal transfer, gene duplication and selection in the evolution of sxtA and sxtG within the dinoflagellates and closely related alveolates, and to examine the diversity of copies of sxtA4 in species of the genus Alexandrium.

\section{Material and methods}

\subsection{Culture maintenance}

Twenty-one strains of Alexandrium species (Table 1) were obtained from the culture collections: the University of Tasmania culture collection, The National Centre for Culture of Marine Phytoplankton (CCMP strain numbers), Australian National Algae Culture Collection (CS strain numbers) and the Cawthron Institute culture collection of microalgae (CAWD strain numbers) (Table 1, strains in bold). Alexandrium fundyense strains $\mathrm{A} 8$ and E4 were isolated from the north-east coast of Scotland (N57 54 '97.22', E-1 ${ }^{\circ} 57^{\prime} 38.89^{\prime \prime}$ ) in 2010 by Yameng Lu. Species names for the Alexandrium tamarense species complex are in accordance with the most recent taxonomic treatment (John et al., 2014), in which Group I ribotype are referred to Alexandrium fundyense, Group II are referred to $A$. mediterraneum, Group III are referred to A. tamarense, Group IV are referred to A. pacificum and Group V to A. australiense.

Strains were grown in K, GP or GSe-medium (Keller et al., 1987; Doblin et al., 1999) prepared from filter-sterilized ( $0.2 \mu \mathrm{m}$ VacuCap 90 filter units, Pall Corporation, Port Washington) seawater 
Table 1

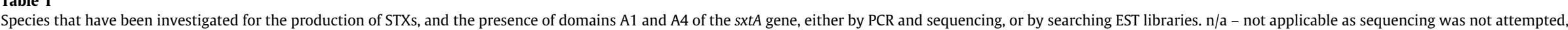

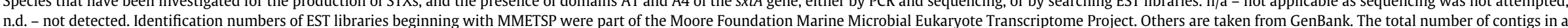

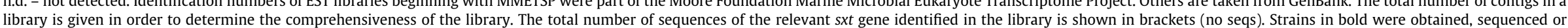
searched in this study.

\begin{tabular}{|c|c|c|c|c|c|c|c|c|c|c|}
\hline \multirow[t]{2}{*}{ Genus } & \multirow[t]{2}{*}{ Species } & \multirow[t]{2}{*}{ Strain } & \multirow{2}{*}{$\begin{array}{l}\text { Documented to produce } \\
\text { STXs? }\end{array}$} & \multirow{2}{*}{$\begin{array}{l}\text { Method for } \\
\text { identification of sxtA } \\
\text { domains }\end{array}$} & \multicolumn{2}{|l|}{ EST library } & \multicolumn{3}{|c|}{ Genes identified or sequenced } & \multirow[t]{2}{*}{ Reference } \\
\hline & & & & & ID no. of library & $\begin{array}{l}\text { Total no. of } \\
\text { contigs in library }\end{array}$ & $\begin{array}{l}\text { sxtA1 } \\
\text { (no. } \\
\text { seqs) } \\
\end{array}$ & $\begin{array}{l}\text { sxtA4 } \\
\text { (no. seqs) }\end{array}$ & $\begin{array}{l}\text { sxtG } \\
\text { (No. } \\
\text { seqs) }\end{array}$ & \\
\hline \multicolumn{11}{|l|}{ Gonyaulacales } \\
\hline \multirow[t]{8}{*}{ Alexandrium } & fundyense & CCMP1719 & Yes (Orr et al., 2011) & PCR & - & - & Yes & Yes & Yes & $\begin{array}{l}\text { Stüken et al. (2011), Orr } \\
\text { et al. (2013) }\end{array}$ \\
\hline & & CCMP1979 & Yes (Orr et al., 2011) & PCR & - & - & Yes & Yes & & Stüken et al. (2011) \\
\hline & & OF101 & Yes (Scholin et al., 1994) & PCR & - & - & $\mathrm{n} / \mathrm{a}$ & Yes & & John et al. (2014) \\
\hline & & SPE10-10-3 & Yes (Hackett et al., 2013) & PCR & - & - & $\mathrm{n} / \mathrm{a}$ & Yes & & John et al. (2014) \\
\hline & & C8 & Yes & PCR & - & - & $\mathrm{n} / \mathrm{a}$ & Yes & & This study \\
\hline & & E4 & Yes & PCR & - & - & $\mathrm{n} / \mathrm{a}$ & Yes & & This study \\
\hline & & ACQH01 & Yes (Scholin et al., 1994) & PCR & - & - & $\mathrm{n} / \mathrm{a}$ & Yes & & John et al. (2014) \\
\hline & & $\begin{array}{l}\text { AtGTM253, 38- } \\
\text { 3, SPE10-03 }\end{array}$ & Yes (?) & EST & 169259 & 92,394 & Yes (2) & Yes (1) & Yes (3) & Hackett et al. (2013) \\
\hline \multirow[t]{2}{*}{ Alexandrium } & mediterraneum & SZN01 & No & PCR & & & $\mathrm{n} / \mathrm{a}$ & n.d. & & John et al. (2014) \\
\hline & & SZN08 & No & PCR & & & $\mathrm{n} / \mathrm{a}$ & n.d. & & John et al. (2014) \\
\hline \multirow[t]{4}{*}{ Alexandrium } & tamarense & ATSW01-1 & No & PCR & & & $\mathrm{n} / \mathrm{a}$ & n.d. & & John et al. (2014) \\
\hline & & CCMP1771 & No & PCR & & & Yes & (?) yes & & Stüken et al. (2011) \\
\hline & & CCMP1771 & No & EST & $\begin{array}{l}\text { MMETSP0384 } \\
\text { MMETSP0382 }\end{array}$ & $\begin{array}{l}106,664 \text { and } \\
98,253\end{array}$ & Yes (2) & n.d. & n.d. & This study \\
\hline & & ATSP1-B & No & EST & prjna169250 & 94,313 & Yes (1) & n.d. & n.d. & Hackett et al. (2013) \\
\hline \multirow[t]{11}{*}{ Alexandrium } & pacificum & CCMP1493 & $\begin{array}{l}\text { Yes (Dantzer and Levin, } \\
\text { 1997) }\end{array}$ & PCR & - & - & Yes & Yes & Yes & $\begin{array}{l}\text { Stüken et al. (2011), Orr } \\
\text { et al. (2013) }\end{array}$ \\
\hline & & CS-300/01 & Yes uncharacterised & PCR & - & - & Yes & Yes & & This study \\
\hline & & CS-315 & Yes uncharacterised & PCR & - & - & Yes & Yes & & This study \\
\hline & & CS-313/01 & Yes uncharacterised & PCR & - & - & Yes & Yes & & This study \\
\hline & & CS-798 & Yes uncharacterised & PCR & - & - & Yes & Yes & & This study \\
\hline & & ACTRA02 & Yes (Murray et al., 2011a,b) & PCR & - & - & Yes & Yes & & $\begin{array}{l}\text { This study; Stüken et al., } \\
2011\end{array}$ \\
\hline & & CAWD44 & Yes (MacKenzie et al., 2004) & PCR & - & - & Yes & Yes & & This study \\
\hline & & CAWD121 & Yes (MacKenzie et al., 2004) & PCR & - & - & Yes & Yes & & This study \\
\hline & & CCMP1598 & Yes & EST & 163,063 & 151,525 & Yes (5) & Yes (2) & Yes (4) & This study \\
\hline & & ACCCO1 & Yes (Murray et al., 2011a,b) & PCR & - & - & Yes & Yes & Yes & $\begin{array}{l}\text { This study; Stüken et al., } \\
\text { 2011; Orr et al., } 2013\end{array}$ \\
\hline & & ACSHO2 & Yes (Murray et al., 2011a,b) & PCR & - & - & Yes & Yes & & $\begin{array}{l}\text { This study; Stüken et al., } \\
2011\end{array}$ \\
\hline \multirow[t]{4}{*}{ Alexandrium } & australiense & АТВВ01 & $\begin{array}{l}\text { Yes/no (Orr et al., 2011; } \\
\text { Murray et al., 2012a,b) }\end{array}$ & PCR & - & - & Yes & Yes & & Stüken et al. (2011) \\
\hline & & ATCJ33 & No (Stüken et al., 2011) & PCR & - & - & Yes & Yes & & $\begin{array}{l}\text { This study; Stüken et al., } \\
2011\end{array}$ \\
\hline & & ATNWB01 & Yes (Murray et al., 2012a,b) & PCR & - & - & Yes & Yes & & Stüken et al. (2011) \\
\hline & & АТЕВ01 & No (Stüken et al., 2011) & PCR & - & - & Yes & Yes & & Stüken et al. (2011) \\
\hline Alexandrium & affine & CCMP112 & No & PCR & - & - & n.d. & n.d. & Yes & $\begin{array}{l}\text { Stüken et al. (2011), Orr } \\
\text { et al. (2013) }\end{array}$ \\
\hline \multirow[t]{2}{*}{ Alexandrium } & andersoni & СCMP2222 & No & PCR & - & - & n.d. & n.d. & Yes (1) & $\begin{array}{l}\text { Stüken et al. (2011), Orr } \\
\text { et al. (2013) }\end{array}$ \\
\hline & & & & EST & MMETSP1436 & 42,240 & Yes (1) & n.d. & & This study \\
\hline Alexandrium & concavum & CAWD51 & No & PCR & - & - & Yes & n.d. & & This study \\
\hline Alexandrium & diversaporum & ААКТ01 & No & PCR & - & - & Yes & n.d. & & $\begin{array}{l}\text { This study, Murray et al., } \\
2014\end{array}$ \\
\hline Alexandrium & fraterculus & CAWD52 & No & PCR & - & - & Yes & n.d. & & This study \\
\hline
\end{tabular}




\begin{tabular}{|c|c|c|c|c|c|c|c|c|c|c|}
\hline \multirow[t]{2}{*}{ Genus } & \multirow[t]{2}{*}{ Species } & \multirow[t]{2}{*}{ Strain } & \multirow{2}{*}{$\begin{array}{l}\text { Documented to produce } \\
\text { STXs? }\end{array}$} & \multirow{2}{*}{$\begin{array}{l}\text { Method for } \\
\text { identification of sxtA } \\
\text { domains }\end{array}$} & \multicolumn{2}{|l|}{ EST library } & \multicolumn{3}{|c|}{ Genes identified or sequenced } & \multirow[t]{2}{*}{ Reference } \\
\hline & & & & & ID no. of library & $\begin{array}{l}\text { Total no. of } \\
\text { contigs in library }\end{array}$ & $\begin{array}{l}\text { sxtA1 } \\
\text { (no. } \\
\text { seqs) }\end{array}$ & $\begin{array}{l}\text { sxtA4 } \\
\text { (no. seqs) }\end{array}$ & $\begin{array}{l}\text { sxtG } \\
\text { (No. } \\
\text { seqs) }\end{array}$ & \\
\hline & & CAWD97 & No & PCR & - & - & Yes & n.d. & & This study \\
\hline Alexandrium & insuetum & CCMP2082 & No & PCR & - & - & n.d. & n.d. & Yes & Orr et al. (2013) \\
\hline \multirow[t]{2}{*}{ Alexandrium } & margalefi & CS-322 & No & PCR & - & - & Yes & n.d. & & This study \\
\hline & & & No & EST & $\begin{array}{l}\text { CLC bio } \\
\text { assembly }\end{array}$ & 109943 & Yes & n.d. & & This study \\
\hline \multirow[t]{9}{*}{ Alexandrium } & minutum & CCMP113 & Yes (Orr et al., 2011) & PCR & - & - & Yes & Yes & Yes & $\begin{array}{l}\text { Stüken et al. (2011), Orr } \\
\text { et al. (2013) }\end{array}$ \\
\hline & & ALSP01 & Yes (Orr et al., 2011) & PCR & - & - & Yes & Yes & & Stüken et al. (2011) \\
\hline & & ALSP02 & Yes (Orr et al., 2011) & PCR & - & - & $\mathrm{n} / \mathrm{a}$ & Yes & & Stüken et al. (2011) \\
\hline & & AMAD16 & Yes (Orr et al., 2011) & PCR & - & - & $\mathrm{n} / \mathrm{a}$ & Yes & & Stüken et al. (2011) \\
\hline & & CCMP1888 & Yes (Orr et al., 2011) & PCR & - & - & Yes & Yes & & Stüken et al. (2011) \\
\hline & & CAWD11 & $\begin{array}{l}\text { Yes (MacKenzie and Berkett, } \\
\text { 1997) }\end{array}$ & PCR & - & - & Yes & Yes & & This study \\
\hline & & CAWD12 & $\begin{array}{l}\text { Yes (MacKenzie and Berkett, } \\
\text { 1997) }\end{array}$ & PCR & - & - & Yes & Yes & & This study \\
\hline & & CS-324 & Yes (Negri et al., 2003) & PCR & - & - & Yes & Yes & Yes & $\begin{array}{l}\text { This study; Stüken et al., } \\
\text { 2011; Orr et al., } 2013\end{array}$ \\
\hline & & CS-320/01 & Yes (Orr et al., 2011) & PCR & - & - & Yes & Yes & Yes & $\begin{array}{l}\text { Stüken et al. (2011), Orr } \\
\text { et al. (2013) }\end{array}$ \\
\hline Alexandrium & monilatum & JR08 & No & EST & MMETSP0093 & 95,897 & Yes (1) & n.d. & n.d. & This study \\
\hline \multirow[t]{4}{*}{ Alexandrium } & ostenfeldii & AOVA30 & Yes (Suikkanen et al., 2013) & PCR & - & - & Yes & Yes & & Suikkanen et al. (2013) \\
\hline & & AOF0927 & Yes (Suikkanen et al., 2013) & PCR & - & - & Yes & Yes & & Suikkanen et al. (2013) \\
\hline & & NCH85 & Yes (Suikkanen et al., 2013) & PCR & - & - & Yes & n.d. & & Suikkanen et al. (2013) \\
\hline & & S06/013/01 & Yes (Brown et al., 2010) & PCR & - & - & Yes & n.d. & & Suikkanen et al. (2013) \\
\hline Alexandrium & pseudogonyaulax & CAWD54 & No & PCR & - & - & Yes & n.d. & & This study \\
\hline Alexandrium & tamiyavanichi & & Yes (Hii et al., 2012) & PCR & - & - & Yes & Yes & & Hii et al. (2012) \\
\hline Ceratium & longipes & CCMP1770 & No & PCR & - & - & n.d. & n.d. & & Orr et al., 2012 \\
\hline Ceratium & fusus & & No & EST & $\begin{array}{l}\text { MMETSP1074 } \\
\text { MMETSP1075 }\end{array}$ & $\begin{array}{l}82,514 \\
87,514\end{array}$ & n.d. & n.d. & & This study \\
\hline Coolia & monotis & CAWD98 & No & PCR & - & - & n.d. & n.d. & & Orr et al., 2012 \\
\hline \multirow[t]{2}{*}{ Crypthecodinium } & cohnii & Seligo & No & EST & MMETSP0325 & 70,674 & n.d. & n.d. & & This study \\
\hline & & & & & MMETSP0324 & 68,757 & n.d. & n.d. & & This study \\
\hline \multirow[t]{2}{*}{ Gambierdiscus } & australes & CAWD149 & No & PCR & - & - & n.d. & n.d. & & Orr et al. (2012) \\
\hline & & & No & EST & - & 106,797 & Yes (4) & n.d. & n.d. & This study \\
\hline Gambierdiscus & belizeanus & CCMP401 & No & EST & - & 114,510 & Yes (5) & n.d. & n.d. & This study \\
\hline Gonyaulax & spinifera & CCMP409 & No & EST & MMETSP1439 & 42,076 & Yes (1) & n.d. & n.d. & This study \\
\hline \multirow[t]{3}{*}{ Lingulodinium } & polyedrum & CCMP1931 & No & PCR & - & - & n.d. & n.d. & & Orr et al., 2012 \\
\hline & & & & EST & Genbank & 74,892 & Yes (2) & n.d. & n.d. & This study \\
\hline & & & & EST & MMETSP1035 & 88,741 & Yes (3) & n.d. & n.d. & This study \\
\hline \multirow[t]{2}{*}{ Protoceratium } & reticulatum & CAWD99 & No & PCR & - & - & n.d. & n.d. & & Orr et al. (2012) \\
\hline & & CCMP1889 & No & EST & MMETSP0228 & 78,281 & Yes (1) & n.d. & n.d. & This study \\
\hline Pyrocystis & noctiluca & СCMP732 & No & PCR & - & - & n.d. & n.d. & & Orr et al. (2012) \\
\hline Pyrodinium & bahamense & pbaha01 & Yes (Harada et al., 1982) & EST & MMETSP0796 & 105,175 & Yes (1) & Yes (1) & Yes (2) & This study \\
\hline Thecadinium & kofoidii & SCCAP K-1504 & No & PCR & - & - & n.d. & n.d. & & Orr et al. (2012) \\
\hline \multicolumn{11}{|l|}{ Dinophysiales } \\
\hline Dinophysis & acuminata & DAEP01 & No & EST & MMETSP0797 & 89,951 & Yes (2) & n.d. & n.d. & This study \\
\hline \multicolumn{11}{|l|}{ Gymnodiniales } \\
\hline \multirow[t]{3}{*}{ Amphidinium } & carterae & UIO081 & No & PCR & - & - & n.d. & n.d. & & Orr et al. (2012) \\
\hline & & CCMP1314 & No & EST & MMETSP0258 & 44,378 & n.d. & n.d. & n.d. & This study \\
\hline & & & & & MMETSP0259 & 45,656 & n.d. & n.d. & n.d. & This study \\
\hline Amphidinium & massartii & CS-259 & No & PCR & - & - & n.d. & n.d. & & Orr et al. (2012) \\
\hline & & & & EST & CLC assembly & 54,729 & n.d. & n.d. & n.d. & This study \\
\hline Amphidinium & mootonorum & CAWD161 & No & PCR & - & - & n.d. & n.d. & & Orr et al. (2012) \\
\hline Gymnodinium & aureolum & SCCAP K-1561 & No & PCR & - & & n.d. & n.d. & & Orr et al. (2012) \\
\hline
\end{tabular}




\begin{tabular}{|c|c|c|c|c|c|c|c|c|c|c|}
\hline \multirow[t]{4}{*}{ Gymnodinium } & catenatum & CCMP1937 & Yes (Oshima et al., 1987) & PCR & - & - & Yes & Yes & Yes & $\begin{array}{l}\text { Stüken et al. (2011), Orr } \\
\text { et al. (2013) }\end{array}$ \\
\hline & & GC744 & Yes & EST & MMETSP0784 & 88,811 & Yes (3) & Yes (5) & Yes $(2)$ & This study \\
\hline & & GCTRA01 & Yes (Stüken et al., 2011) & PCR & - & - & Yes & Yes & & Stüken et al. (2011) \\
\hline & & CS-395 & Yes (Stüken et al., 2011) & PCR & - & - & Yes & Yes & & Stüken et al. (2011) \\
\hline \multirow[t]{4}{*}{ Karenia } & brevis & Wilson & No & EST & MMETSP0201 & 89,216 & Yes (2) & n.d. & n.d. & This study \\
\hline & & Wilson & & & MMETSP0640 & 83,137 & Yes (1) & n.d. & n.d. & This study \\
\hline & & Sp1 & & & MMETSP0574 & 99,942 & Yes (3) & n.d. & n.d. & This study \\
\hline & & Sp3 & & & MMETSP0528 & 82,936 & Yes (2) & n.d. & n.d. & This study \\
\hline Karlodinium & veneficum & RCC2539 & No & PCR & - & - & n.d. & n.d. & & Orr et al., 2012 \\
\hline Karlodinium & micrum & CCMP2283 & No & EST & MMETSP1016 & 70,296 & Yes (1) & n.d. & n.d. & This study \\
\hline Lepidodinium & chlorophorum & RCC2537 & No & PCR & - & - & n.d. & n.d. & & Orr et al. (2012) \\
\hline Togula & jolla & CCCM725 & No & EST & MMETSP0224 & 47,727 & n.d. & n.d. & n.d. & This study \\
\hline \multicolumn{10}{|l|}{ Noctilucales } & This study \\
\hline \multicolumn{11}{|l|}{ Oxyrrhinaceae } \\
\hline Oxyrrhis & marina & Unknown & No & EST & MMETSP0469 & 51,092 & n.d. & n.d. & n.d. & This study \\
\hline \multicolumn{11}{|l|}{ Peridiniales } \\
\hline Adenoides & eludens & CCMP1891 & No & PCR & - & - & n.d. & n.d. & & Orr et al. (2012) \\
\hline \multirow[t]{2}{*}{ Azadinium } & spinosum & RCC2538 & No & PCR & - & - & n.d. & n.d. & & Orr et al. (2012) \\
\hline & & 3D9 & No & EST & MMETSP1036 & 75,458 & Yes (1) & n.d. & n.d. & This study \\
\hline Brandtodinium & nutriculum & RCC3387 & No & EST & MMETSP1462 & 68,123 & Yes (2) & n.d. & n.d. & This study \\
\hline Durinskia & baltica & CSIROCS-38 & No & EST & MMETSP0116 & 78,444 & Yes (2) & n.d. & n.d. & This study \\
\hline Glenodinium & foliaceum & CCAP 116/3 & No & EST & MMETSP0118 & 80,537 & n.d. & n.d. & n.d. & This study \\
\hline \multirow{2}{*}{ Heterocapsa } & triquetra & RCC2540 & No & PCR & - & - & n.d. & n.d. & & Orr et al. (2012) \\
\hline & & CCMP448 & No & EST & MMETSP0448 & 62,735 & Yes (1) & n.d. & n.d. & This study \\
\hline Heterocapsa & rotundata & SCCAP K-0483 & No & EST & MMETSP0503 & 46,210 & Yes (1) & n.d. & n.d. & This study \\
\hline Heterocapsa & arctica & CCMP445 & No & EST & MMETSP1441 & 50,206 & Yes (2) & n.d. & n.d. & This study \\
\hline Kryptoperidinium & foliaceum & CCMP1326 & No & EST & MMETSP0120 & 93,725 & Yes (1) & n.d. & n.d. & This study \\
\hline Peridinium & aciculiferum & PAER-2 & No & EST & MMETSP0370 & 64,738 & Yes (1) & n.d. & n.d. & This study \\
\hline Pentapharsodinium & dalei & SCCAP K-1100 & No & PCR & - & - & n.d. & n.d. & n.d. & Orr et al. (2012) \\
\hline \multirow[t]{2}{*}{ Scrippsiella } & trochoideae & BS-46 & No & PCR & - & - & n.d. & n.d. & n.d. & Orr et al., 2012 \\
\hline & & CCMP3099 & & EST & MMETSP0270 & 106,989 & Yes (1) & n.d. & & This study \\
\hline \multicolumn{11}{|l|}{ Prorocentrales } \\
\hline Prorocentrum & $\operatorname{lima}$ & CS-869 & No & PCR & - & - & n.d. & n.d. & & Orr et al., 2012 \\
\hline Prorocentrum & micans & UIO292 & No & PCR & - & - & n.d. & n.d. & & Orr et al., 2012 \\
\hline \multirow[t]{2}{*}{ Prorocentrum } & minimum & UIO085 & No & PCR & - & - & n.d. & n.d. & n.d. & Orr et al., 2012 \\
\hline & & CCMP1329 & & EST & MMETSP0053 & 80,069 & Yes (1) & n.d. & & This study \\
\hline \multicolumn{11}{|l|}{ Suessiales } \\
\hline Pelagodinium & beii & RCC1491 & No & EST & MMETSP1338 & 55,559 & Yes (1) & n.d. & n.d. & This study \\
\hline \multirow[t]{2}{*}{ Polarella } & glacialis & CCMP2088 & No & PCR & - & - & n.d. & n.d. & n.d. & Orr et al., 2012 \\
\hline & & & & EST & MMETSP1440 & 45,295 & Yes (1) & n.d. & & This study \\
\hline Polarella & glacialis & CCMP1383 & No & EST & MMETSP2227 & 74,437 & Yes (1) & n.d. & n.d. & This study \\
\hline \multirow{2}{*}{ Symbiodinium } & sp. & CCMP2430 & No & EST & MMETSP0115 & 47,757 & Yes (1) & n.d. & n.d. & This study \\
\hline & & & No & EST & MMETSP1122 & 47,710 & Yes (1) & n.d. & n.d. & This study \\
\hline
\end{tabular}


(salinity $33-35$ ) at $15-18{ }^{\circ} \mathrm{C}$, with a $14: 10$ or $12: 12$ Light:Dark cycle, and an irradiance of 60-150 $\mu \mathrm{mol}$ photons $\mathrm{m}^{-2} \mathrm{~s}^{-1}$.

\subsection{DNA extraction, PCR amplification, cloning and DNA sequencing}

Alexandrium cells were harvested by centrifugation for $15 \mathrm{~min}$ at $4{ }^{\circ} \mathrm{C}$ at $3220 \mathrm{~g}$ (Eppendorf 5415R, Germany). DNA was extracted using a modified CTAB- phenol- chloroform method (Jørgensen et al., 2004). The DNA quality and concentration was determined using a Nanodrop (Thermoscientific, Australia), amplifying rRNA genes and/or visualising on an agarose gel.

Partial sequences of the rRNA genes LSU and SSU and complete 5.8s/ITS genes were amplified using previously published primers: SS3, SS5 (Medlin et al., 1988), D1R, D3b (Scholin et al., 1994), and ITSfor, ITSrev (Murray et al., 2012a,b). For the amplification of sxtA genes, sxtA1 and sxtA4 domains were amplified using the primers sxt001, sxt002 (A1) and sxt007 and sxt008 (A4) (Stüken et al., 2011). PCR reactions (final volume $25 \mu \mathrm{L}$ ) consisted of $20-100 \mathrm{ng}$ genomic DNA, $0.5 \mu \mathrm{M}$ of forward and reverse primer, BSA at a final concentration of $1 \mu \mathrm{g} / \mu \mathrm{L}$ and $12.5 \mu \mathrm{L}$ of Immomix $^{\mathrm{TM}}$ (Bioline, Australia), which contains Reaction Buffer, $3 \mathrm{mM} \mathrm{MgCl} 2$, polymerase and additives needed to stabilize the polymerase in the reaction mix. The reactions for SSU, LSU and ITS rDNA were carried out using the following programme: $95{ }^{\circ} \mathrm{C}$ for $10 \mathrm{~min}, 31 \times\left(95{ }^{\circ} \mathrm{C}\right.$ for $40 \mathrm{~s}, 55^{\circ} \mathrm{C}$ for $40 \mathrm{~s}, 72{ }^{\circ} \mathrm{C}$ for $1 \mathrm{~min}$ ), $72^{\circ} \mathrm{C}$ for $7 \mathrm{~min}$ with the primers described in Table 2, using the Verity ${ }^{\circledR}$ Thermal Cycler (Life Technologies, Australia).

The PCR reactions to amplify the sxtA1 and sxtA4 genes were carried out in a final volume of $25 \mu \mathrm{L}$. The reaction mix consisted of 20-100 ng of DNA, and $0.2 \mathrm{mM}$ dNTPs, $0.5 \mu \mathrm{M}$ of each forward and reverse primer, 0.25 units of $50 \times$ GC2 Advantage Polymerase Mix (BD Biosciences) consisting of $0.25 \%$ Glycerol, $0.075 \mathrm{mM}$ Tris-Glycerol (ph-8.0), $0.375 \mathrm{mM} \mathrm{KCl}, 0.25 \mu \mathrm{M}$ EDTA and 1 unit of Advantage GC Buffer (BD Biosciences, Australia), which includes $40 \mathrm{mM}$ Tricine- $\mathrm{KOH}, 5 \mathrm{mM} \mathrm{KOAc} 1,3.5 \mathrm{mM} \mathrm{Mg}(\mathrm{OAc}) 2$, 5\% DMSO, $3.75 \mu \mathrm{g} / \mathrm{mL}$ BSA, $0.005 \%$, Nonidet P-40, 0.005\% Tween-20, and 1 unit of 5 M GC Melt solution, which aids in the successful amplification of GC-rich dinoflagellate sequences. Alternatively, $20 \mu \mathrm{L}$ PCR reactions were carried out using HotMasterTaq ${ }^{\circledR}$ (5Prime, Hamburg, Germany) buffer $1 \times, 0.1 \mathrm{mM}$ of dNTPs, $0.1 \mathrm{mM}$ of each forward and reverse primer, 0.75 units of Taq polymerase, and 10-30 ng of genomic DNA. sxtA1 was amplified with the following programme: $94{ }^{\circ} \mathrm{C}$ for $3 \mathrm{~min}, 31 \times\left(94{ }^{\circ} \mathrm{C}\right.$ for $30 \mathrm{~s}, 60^{\circ} \mathrm{C}$ for $30 \mathrm{~s}$, $68^{\circ} \mathrm{C}$ for $1 \mathrm{~min}$ ), $68^{\circ} \mathrm{C}$ for $3 \mathrm{~min}$. sxtA4 was amplified as follows: $94^{\circ} \mathrm{C}$ for $3 \mathrm{~min}, 31 \times\left(94^{\circ} \mathrm{C}\right.$ for $30 \mathrm{~s}, 57^{\circ} \mathrm{C}$ for $30 \mathrm{~s}, 68^{\circ} \mathrm{C}$ for $1 \mathrm{~min}), 68^{\circ} \mathrm{C}$ for $3 \mathrm{~min}$. DNA was visualised on an agarose gel with GelRedTM (Biotium, Australia). Fragments were excised and purified (Zymogen Gel extraction Kit).

Purified PCR products were ligated into the $\mathrm{PCR}^{\circledR} 4$-TOPO ${ }^{\circledR}$ vector with the $\mathrm{TOPO}^{\circledR} \mathrm{TA}$ cloning kit (Invitrogen, Darmstadt, Germany) according to the manufacturer's instructions. $4 \mu \mathrm{L}$ of the purified PCR product was mixed with $2 \mu \mathrm{L} 5 \times$ Advantage GC Buffer (BD Biosciences), $0.2 \mathrm{mM}$ dNTPs and $0.1 \mu \mathrm{L}$ of $50 \times \mathrm{GC} 2$ Advantage Polymerase Mix (BD Biosciences) and incubated at $68{ }^{\circ} \mathrm{C}$ for 5 min to carry out poly-A tailing of the PCR product. Poly-A tailed PCR products were stored at $-20^{\circ} \mathrm{C}$ till required for transformation. For the transformation, $2 \mu \mathrm{L}$ of $\mathrm{pCR}^{\circledR} 4-\mathrm{TOPO}^{\circledR}$ vector ligation mix was mixed with $25 \mu \mathrm{L}$ of One Shot ${ }^{\circledR}$ TOP10 chemically E. coli cells (Invitrogen, Darmstadt, Germany). Cells were incubated at $45^{\circ} \mathrm{C}$ then mixed with $250 \mu \mathrm{L}$ Super Optimal Broth (SOB, Invitrogen, Darmstadt, Germany). Cells were incubated at $37^{\circ} \mathrm{C}$ with shaking at $250 \mathrm{rpm}$ for an hour, plated on pre-warmed Lysogeny Broth agar plates and incubated at $37^{\circ} \mathrm{C}$ overnight. Colonies were exised and M13 PCR was performed according to the manufacturer's instructions. PCR reactions were cleaned using SureClean Plus (Bioline, Australia) and checked on a 1\% agarose gels. Reactions were sequenced by Sanger sequencing at Macrogen, Korea, AWI or at Ramaciotti Centre for Genomics, Australia. All sequences were submitted to GenBank (Supplementary Table 1).

\subsection{Assembly and analyses of EST libraries}

EST libraries from thirty-six species (forty-six libraries) of dinoflagellates were investigated for the presence or absence of sxtA1, sxtA4 or sxtG contigs. These consisted of every publicly available library of a species of Alexandrium, in particular those that were part of the Marine Microbial Eukaryote Transcriptome Sequencing Program (MMETSP) (http://marinemicroeukaryotes. $\operatorname{org} /$ ), and representative libraries from other dinoflagellate families. We limited our searches to only the most comprehensive publicly available transcriptome libraries, which we judged as those with a sequence depth of a least 40,000 unique contigs after assembly, as we wanted the highest possible likelihood that an inability to find an sxtA domain was not due to limitations in EST sequencing methods or library completeness (Table 1 ).

Custom BLAST searches were performed in Geneious software (Kearse et al., 2012). Alexandrium transcriptomes were queried against a local database of sxtA1, sxtA4 (JA343240-JF343356) (Stüken et al., 2011) and sxtG (JX995111-JX995130) (Orr et al., 2013) sequences with an e-value cutoff of $10^{-3}$. A similarity of $90 \%$ with a minimum hit length of 250 bp or more was taken as a positive hit for both sxtA1 or sxtA4. A conserved domain database search (Marchler-Bauer et al., 2011) on NCBI website was conducted on extracted positive sequences, to confirm that the sequences have a predicted functionality of a SAM-dependent methyltransferase (sxtA1) or class II aminotransferase (sxtA4). Due to high similarity between sxt $G$ and other amidinotransferases in EST libraries, phylogenetic analysis was performed to differentiate between $s x t G$ and other amidinotransferases.

In addition, thirteen EST libraries of other alveolates: nine species of Ciliata, two Perkinozoa, one Chromerida and one Apicomplexa, were investigated for the presence or absence of sxtA1, sxtA4 or sxtG using the method described above (Supplementary Table 2).

\subsection{Phylogenetic analyses}

The three-rDNA genes (18S, 5.8S, and 28S) were separately aligned using the MAFFTv7 Q-INS-I model (Katoh and Toh, 2008), considering secondary RNA structure (default parameters used). The five protein coding datasets (actin, beta-tubulin, cob, cox1, and hsp90) were separately aligned at the nucleotide level based on the corresponding amino acid alignment, as to maintain codon integrity, inferred with MAFFTv7 G-INS-I model (default parameters used). To increase phylogenetic signal, allowing for synonymous substitutions, the nucleotide sequence (3rd codon removed) was used for subsequent inferences. Outgroup taxa were established from previous dinoflagellate and protist phylogenies (Murray et al., 2005; John et al., 2003; Shalchian-Tabrizi et al., 2006; Orr et al., 2013). All single gene alignments were checked manually using Mesquite v3.0 (Maddison and Maddison, 2011). The eight separate alignments were then checked with Gblocks v0.91b (Castresana, 2000), under the least stringent parameters (small final block, gap positions in final block and less strict flanking), to exclude poorly aligned positions and divergent regions from subsequent phylogenetic inferences. The alignments were then concatenated into a supermatrix. For the supermatrix (concat) in-group taxa (dinoflagellates) required rDNA sequence data in addition to two of the five protein coding genes. The only exception to this was species of the Alexandrium genus, whose inclusion was considered paramount to the studies' aim, and which were 


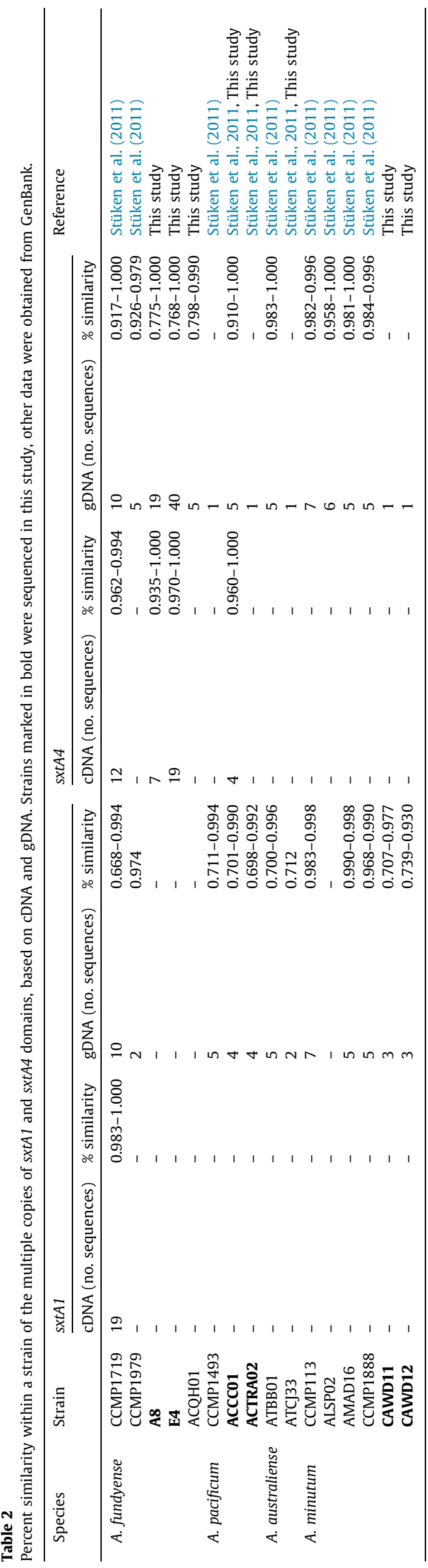

included even when only the rDNA sequence information was present (Wiens, 2005). Maximum Likelihood (ML) analyses were performed with RAxML-VI-HPCv8.0.0, GTRCAT model with 25 rate categories (Stamatakis, 2006). Bayesian inference was carried out using Phylobayes v3.3f (Lartillot et al., 2009) under the GTRCAT substitution model with a free number of mixing categories and a discrete across site variation under 4 categories. Trees were inferred when the largest maximum difference between the bipartitions (chains) was $<0.1$. The mitochondrial cytochrome genes, cob and cox 1 were excluded for Heterocapsa species; the mitochondrial genes for this genus have been shown to have a high divergence rate resulting in an artificial evolutionary placement (Orr et al., 2012).

Three dinoflagellate genes sxtA1, sxtA4 and sxtG were aligned with orthologous amino acid cyanobacterial sequences, apart from sxtA4, for which we also aligned nucleotide sequences, and a selection of closely related NCBInr BLASTP hits using MAFFTv7 L-INS-I model under the default settings. The resulting alignments were checked manually, and poorly aligned positions were excluded using Mesquite v3.0. ProtTest v2.4 (Abascal et al., 2005) determined LG as the optimal evolutionary model for all alignments. Maximum likelihood (ML) analyses were performed with the RAxML-VI-HPC v8.0.0, PROTCATLG model with 25 rate categories. The most likely topology was established from 100 separate searches, and bootstrap analyses were performed with 1000 pseudoreplicates. Bayesian inference was carried out using Phylobayes v3.3f (Lartillot et al., 2009) under the LGCAT substitution model, as previously described. All model estimation and phylogenetic analyses were done using either Lifeportal (https://lifeportal.uio.no) or the abel server at the University of Oslo.

\subsection{Selection analyses}

Codon-based alignments for dinoflagellates including representatives of all clades of $s x t G$ and sxtA1 were generated. Tests for branches and sites under selection were conducted using Branch-site REL (Pond et al., 2011), as implemented using the datamonkey web interface (www.datamonkey.org). Branch-site REL performs likelihood ratio tests to identify which lineages in a phylogeny have a proportion of sites that evolved with $\mathrm{d} N / \mathrm{d} S$ significantly greater than 1 , which would indicate instances of episodic diversifying selection at some sites in the alignment. Branch-site REL does not require assumptions about which lineages those are, and what happens to the rest of the lineages, as these assumptions could lead to false positives and loss of statistical power (Pond et al., 2011). Probability values are corrected for multiple testing using the Holm Bonferroni method (Pond et al., 2011).

\section{Results and discussion}

\subsection{Phylogeny of dinoflagellates, including the genus Alexandrium}

The phylogenetic analysis of dinoflagellates (Fig. 1) including the new gDNA sequences of SSU generated in this study, ITS1/5.8s/ITS2, partial LSU rDNA and the newly identified sequences from transcriptome libraries of actin, beta-tubulin, cytochrome b and cox1 showed that the genus Alexandrium was fully supported as a monophyletic clade $(100 \% / 1.00$, BS/PP). Our phylogeny showed moderate support for the divergence between armoured and unarmoured dinoflagellates (57/0.82), a similar level to that found in a study, which was the first to demonstrate support for this split (Orr et al., 2012). There was support for the monophyly of the major orders of dinoflagellates, including Gonyaulacales (100/1.00), Peridiniales excluding Heterocapsa (58/0.86), Suessiales (100/1.00), Prorocentrales (82/0.93), while 
Gymnodiniales were paraphyletic, and were sister group to the armoured dinoflagellates (Fig. 1). The most basal lineage of "core" dinoflagellates was shown to be the genus Amphidinium, as has been found previously (Jørgensen et al., 2004; Zhang et al., 2007; Orr et al., 2012). The species Gymnodinium catenatum was clearly part of the Gymnodinium sensu stricto clade (100/1.00).

The fully supported Alexandrium clade was within the order Gonyaulacales, and was sister group to a clade consisting of Gambierdiscus spp. and Pyrocystis spp, with Pyrodinium bahamense as sister group to that (Fig. 1). This topology was the same in the analysis on the reduced alignment, including only those species for which all genes were present (data not shown). Within Alexandrium, two main clades were identified, although each was only moderately supported $(61 / 0.78,64 / 0.94)$, which consisted of the group of species: A. margalefi, A. leei, A. diversaporum, A. minutum, A. tamutum, A. andersoni, A. ostenfeldii, and the group of species A. monilatum, A. satoanum, A. taylori, A. pseudogonyaulax, A. hiranoi, A. affine, A. fraterculus, A. tropicale, A. tamiyavanichi, as well as the $A$. tamarense species complex group (A. fundyense, A. mediterraneum, A. tamarense, A. pacificum, and A. australiense (John et al., 2014)). The Alexandrium species producing STXs (highlighted in Fig. 1) included some representatives from both major Alexandrium clades (Fig. 1), as well as the species Pyrodinium bahamense and Gymnodinium catenatum.

\subsection{Presence of sxtA domains $A 1$ and $A 4$, and sxtG}

The species of Alexandrium that are established to produce STXs are: Alexandrium minutum, A. ostenfeldii, A. australiense (these three species also include some non-STX producing strains (Yang et al., 2010; Touzet et al., 2007; Murray et al., 2012a,b; Kremp et al., 2014), A. pacificum, A. fundyense, and A. tamiyavanichi. We searched for sxtA domains in the following strains which were known to produce STXs: fifteen strains of species of Alexandrium, one strain of Gymnodinium catenatum and one strain of Pyrodinium bahamense, using PCR (14 strains) and by searching transcriptome libraries (3 strains) (Table 1). An analysis of the presence of sxtA in dinoflagellates from our new data and all previous reports (Table 1, data from PCRs in current study in bold), shows that all species which produced STX possessed the domain $s x t A 4$. In detail, we have confirmed the presence of $s x t A$, domain $A 4$, in 40 strains of 8 species of STX-producing dinoflagellates, and did not identify it in 67 strains of 54 species of non STX-producing species representing different dinoflagellate families (Table 1 ). These results confirmed the hypothesis that sxtA4 is an essential domain for saxitoxin synthesis (Kellmann et al., 2008; Stüken et al., 2011; Murray et al., 2011a,b). Conversely, only those species which could produce this toxin possessed this domain, apart from one interesting anomaly: all four strains of Alexandrium australiense (formerly A. tamarense, Group $\mathrm{V})$, only two of which have been found to produce STXs, possess the domain sxtA4 (Orr et al., 2011; Murray et al., 2012a,b). The finding of sxtA4 in one strain (CCMP1771) of A. tamarense, (former A. tamarense, Group III, John et al., 2014), in a previous study (Stüken et al., 2011) has not been confirmed in this study, or a previous study (John et al., 2014). A search of two comprehensive transcriptomic libraries of CCMP1771, failed to find a sequence of sxtA, domain 4 (Table 1). Similarly, a study of a different strain of Alexandrium tamarense (formerly Group III) failed to find this sequence (Hackett et al., 2013). Alexandrium tamarense (sensu John et al., 2014) is not known to produce STXs, and so this finding is in line with the pattern we have observed.

Eight strains of STX-producing Alexandrium fundyense (formerly, Group 1) possess both the domain sxtA1 and the domain sxtA4. Similarly, these two domains were found in eleven strains of STX producing Alexandrium pacificum (formerly, A. catenella, Group IV, John et al., 2014); nine strains of STX-producing Alexandrium minutum, four strains of Alexandrium australiense; four strains of STX producing Gymnodinium catenatum, two strains of Alexandrium ostenfeldii, and a single strain each of Alexandrium tamiyavanichi and Pyrodinium bahamense (Table 1, Stüken et al., 2011; Murray et al., 2012a,b; John et al., 2014; Hackett et al., 2013; Suikkanen et al., 2013).

The species of Alexandrium examined, which lacked the domain sxtA4, were: Alexandrium mediterraneum (formerly A. tamarense Group II), A. tamarense (formerly Group III), A. affine, A. andersoni (CCMP2222), A. concavum, A. diversaporum, A. fraterculus, A. insuetum, A. margalefi, A. monilatum, A. pseudogonyaulax (Table 1). This indicates that these strains may lack the ability to synthesise STXs. It has been reported that a strain of $A$. affine can produce low levels of STX (Nguyen Ngoc, 2004), while other studies have found that strains do not produce STXs (Hallegraeff et al., 1991; Band-Schmidt et al., 2003; Stüken et al., 2011; Wang et al., 2006). A strain of Alexandrium andersoni (CCMP2222) was reported to produce low levels of STXs (Ciminiello et al., 2000; Frangopulos et al., 2004), while other studies based on CCMP2222 and other strains of $A$. andersoni have not detected STXs (Sampedro et al., 2013; Stüken et al., 2011; Orr et al., 2011; Touzet et al., 2008). It is possible that sxtA related genes are no longer expressed in CCMP2222, or that early reports of STX production were in error.

We searched for sxtA domains in EST libraries from 28 additional dinoflagellates, which were not species of the genus Alexandrium and non-STX producers. We found that $s x t A$, domain $A 4$, was not present in the transcriptomes of these species (Table 1). However, we found a paralog of the domain sxtA1 to be present in the majority of the non-toxic dinoflagellate species, including in non-STX producing species of Alexandrium (Table 1).

For $s x t G$, we searched the all EST libraries of all dinoflagellate strains available (Table 1 ). We found $s x t G$ was present in the transcriptome of the three strains of STX producing dinoflagellates: $A$. fundyense, A. pacificum CCMP1598, Pyrodinium bahamense (Table 1). It was not found in the transcriptomes of the non-STX producing species of Alexandrium or other dinoflagellates (Table 1). This result is in contrast with Orr et al., 2013, in which sxtG was found in 3 non-STX producing Alexandrium species, as well as 7 species of STX-producing Alexandrium.

We searched EST libraries from nine ciliates, two Perkinozoa, one Chromerida and one Apicomplexa and found that $s x t A$, domain $\mathrm{A} 1$ and $\mathrm{A} 4$ and $s x t G$ were not present in the transcriptome of these alveolate species (Supplementary Table 2).

\subsection{Intraspecific variation in sxtA1 and sxtA4 domains}

Approximately 100-378 genomic copies of sxtA4 gene cell ${ }^{-1}$ have been reported for three strains of Alexandrium pacificum (Stüken et al., 2011; Murray et al., 2011b), which appears to be an average number of copies for a moderately expressed gene in a dinoflagellate (i.e. Le et al., 1997; Bachvaroff and Place, 2008). Expressed transcripts of sxtA4 have been reported to differ from one another in A. fundyense and A. minutum (Stüken et al., 2011We examined intragenomic diversity differences within the sequences of cDNA as compared to gDNA for three strains of $A$. fundyense and one strain of $A$. pacificum for sxtA4 and one strain of $A$. fundyense for sxtA1 (Table 2). Transcription appears to limit the diversity of copies of the sxtA4 and sxtA1 domains (Table 2), as the overall\% similarity was consistently higher for cDNA copies than gDNA copies, indicating that only certain gDNA copies are transcribed. It is likely that some of the gDNA copies are pseudogenes, as a deletion of 63 bases was found in some of the gDNA sequences from $A$. fundyense strains $\mathrm{E} 4$ and $\mathrm{A} 8$, whereas no gap was observed in the corresponding cDNA copies from the same strains. No deletion was found in sequences from CCMP1719, of 


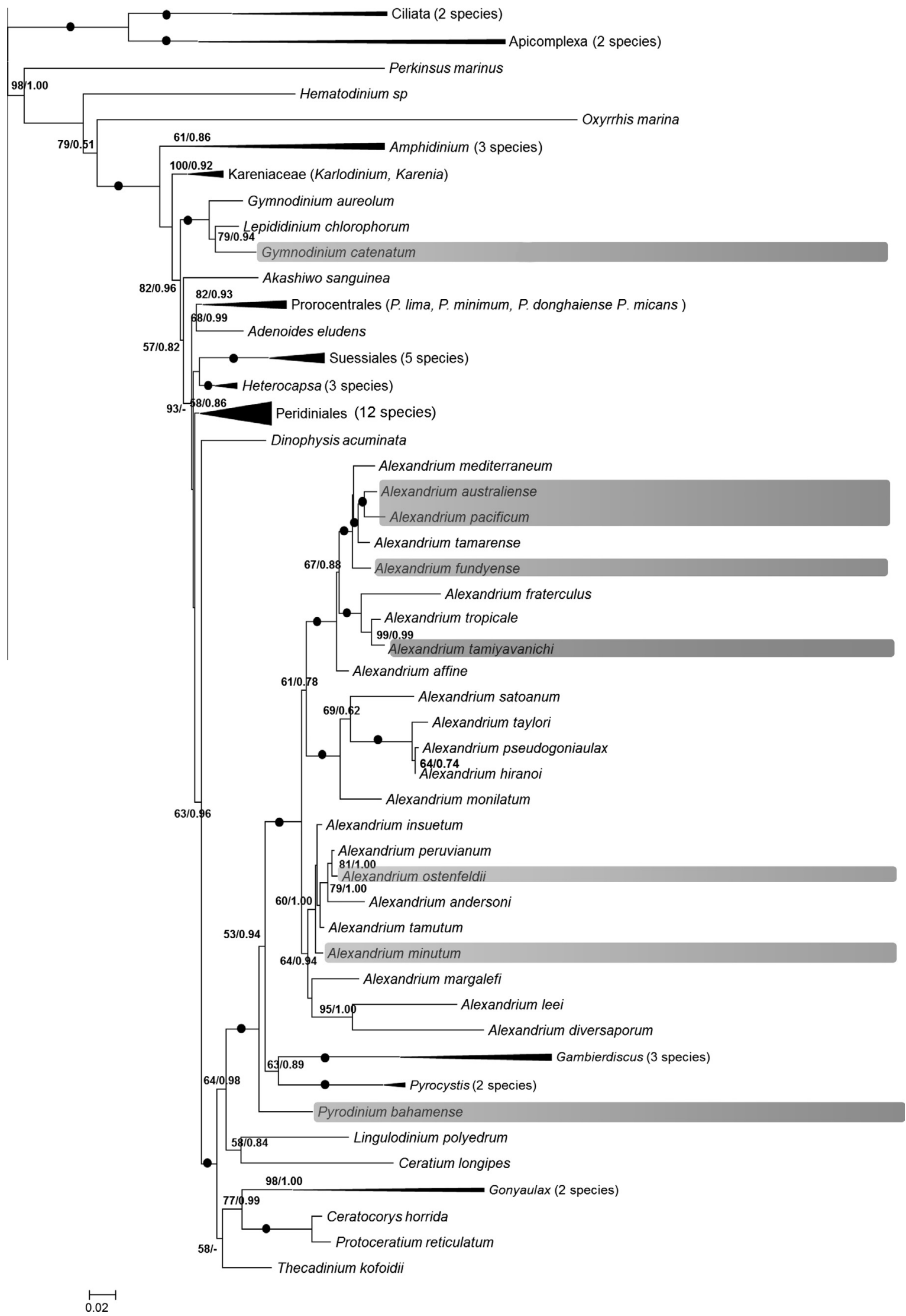

Fig. 1. Phylogeny of dinoflagellates, including the genus Alexandrium, based on a concatenated alignment of 8 genes (7308 bp). Support values at nodes represent ML bootstrap values based on 1000 replicates and Bayesian Posterior probabilities (BS/PP). Boxes highlighted show species which are known to produce PSTs. Scale bar indicates the number of substitutions per site. 
A. fundyense, suggesting a further strain-specific variability within this species.

In a comparison of the cDNA sequences with the gDNA sequences of each strain, and there were certain base positions for which the bases were consistently different for the cDNA sequences, as compared to the gDNA sequences. In strain E4, there were 6 sites at which different bases were found in almost all of the transcribed sequences as compared to the gDNA, including a gap, which resulted in a frame shift in the protein (data not shown). In A. fundyense strain CCMP1719, three sites were identified which differed consistently, apart from in a single gDNA. It has been reported that in A. pacificum strain ACCC01, there were 19 sites at which differences were apparent between almost all cDNA clones, and these correlated with one of the gDNA clones (Wiese, 2012). This is similar to the finding of an analysis of gDNA and cDNA copies of actin in Amphidinium carterae Hulburt, in which some pseudogenes were found, and transcriptional and post-transcriptional processes appeared to reduce diversity in actin copies (Bachvaroff and Place, 2008). Therefore it is likely that transcriptional and post-transcriptional processes also serve to limit the diversity of sxtA sequences in Alexandrium. However, this pattern was not universal, as no consistent differences were observed in A. fundyense strain A8 between the gDNA and cDNA clones. The presence of multiple, slightly different genomic copies of sxtA4 may provide adaptive plasticity of strains and may partly explain the broad phenotypic diversity in terms of STX profile and toxicity within Alexandrium populations (Alpermann et al., 2010; Kremp et al., 2012). Additional information on the sxtA genes in different species of STX producing Alexandrium species may lead to a greater clarification of the relationship between toxicity and sxtA gene diversity, copy number and expression in Alexandrium.

\subsection{Phylogeny of sxtA1, sxtA4, and sxtG}

Paralogs of sxtA4 in every dinoflagellate STX producing species were found to form a monophyletic clade with full support (100/1.00, Fig. 2A). The dinoflagellate clade was highly conserved, and the sister group to cyanobacterial sxtA4 (Fig. 2A). In the analysis based on the nucleotide alignment, (Fig. 2B) the species Alexandrium minutum, A. australiense, A. ostenfeldii, Gymnodinium catenatum, and Pyrodinium bahamense appeared to have largely distinctive sxtA4 copies, which did not group with copies from any other species (Fig. 2B). There was little evidence of widespread horizontal transfer amongst all species of Alexandrium (Fig. 2B). Within closely related species, for example those of the $A$. tamarense species complex, $A$. pacificum and $A$. fundyense, sequences from different clonal strains from these two species formed a single clade, albeit with little or no support, indicating either a common evolutionary history or similar functional constraints (Fig. 2B). One possibility is that, as these two species have diverged comparatively recently (Fig. 1 ), their sxtA copies may not be sufficiently distinct as yet. One sequence apparently from $A$. minutum was included in this clade, which, if confirmed, might suggest that there may be some genetic exchange amongst species. We have no models how this might functionally have been happened amongst species within the genus. Therefore, a more likely evolutionary scenario may argue that different mutation rates within and amongst species has resulted in this unusual placement (Fig. 2B).

The phylogeny of sxtA1 (Fig. 3) shows that three paralogs with moderate to high support were present in dinoflagellates. One paralog, clade 2 , formed a highly supported clade (98/1.00) that appeared to be made up of species that produce STXs: A. minutum, A. pacificum, A. australiense, A. fundyense, Pyrodinium bahamense and Gymnodinium catenatum, as well as two genomic sequences from the non-STX producing species $A$. margalefi and A. pseudogonyaulax (Fig. 3). In the EST library of the same strain of $A$. margalefi investigated in this study (Table 1 ), the corresponding cDNA sequence similar to this sxtA1 gDNA copy was not found, suggesting that it might be a pseudogene or may not be highly expressed, and therefore not detected.

A further paralog, clade 3 , was made up of sequences from almost every dinoflagellate family and order, including Gymnodiniales (Karenia), Peridiniales (Scrippsiella, Heterocapsa), Suessiales (Symbiodinium, Pelagodinium), and Gonyaulacales (Lingulodinium, Gonyaulax, Protoceratium, Gambierdiscus). The structure of this group overall was not well supported $(-/ 0.84)$. However some clades showed high support, such as the paralogs from Heterocapsa species, which grouped together with high support (99/1.00), and the second clade from Alexandrium species, which also grouped together with high support (96/1.00; Fig. 3).

Finally, clade 1 of sxtA1 (Fig. 3) was composed of sequences from Alexandrium species, which are either known to not produce STXs, or are known to have toxic and non-toxic strains (A. minutum, e.g. Yang et al., 2010; Touzet et al., 2007). As sequences of this clade were not recovered from almost all STX producing strains, it is unlikely that these sequences are necessary for STX production, suggesting that this clade may be comprised of a pseudogene or paralog with a separate function to STX production.

The phylogeny of $s x t G$ (Fig. 4) shows that one clade (sxtG) was highly conserved, and well supported, and included all of the species known to produce STX, including Gymnodinium catenatum, Pyrodinium bahamense, A. minutum, A. pacificum, A. fundyense and $A$. australiense. This clade includes sequences from gDNA for $A$. andersoni, A. insuetum and $A$. affine from a previous study (Fig. 4, Orr et al., 2013). In contrast, in this study, sxtG was not found in any of the transcriptomes of species not known to produce STX (Table 1). This gene appears to be related to a bacterial clade including the cyanobacterial sxtG. This gene is consequently interpreted to be the clade involved in STX biosynthesis. However, as expected, many similar amidinotransferase enzymes, a common functional enzyme domain, were also found throughout the dinoflagellates (clades $1,2,3$ ). These were in separate, generally well-supported clades (84/1.00, 100/1.00, 93/0.99, for clades 1, 2, 3 respectively), which included enzymes from many bacterial species as sister groups, and the amidinotransferase enzymes from cylindrospermopsin producing cyanobacteria, cyrA. These paralogs were widely presented in dinoflagellates examined, including species of every dinoflagellate order, as well as closely related or basal species such as Oxyrrhis marina and Perkinsus marinus, pointing to a more common presented function for these genes within the dinoflagellates.

\subsection{The evolution of sxt genes within the dinoflagellates}

The phylogenies of sxtA1 and sxtG did not show a clear similarity in topology with the species phylogeny of those dinoflagellates possessing these paralogs, indicating that the evolution of these genes has been complex. The possession of multiple paralogs of sxtA1 and sxt $G$ adds to the complexity of the interpretation of these phylogenies. However, within the phylogeny based on nucleotides of $s x t A 4$, clade 1 of $s x t A 1$, as well as in $s x t G$, the copies present in Pyrodinium bahamense and Gymnodinium catenatum appear distinctive when compared with the copies in Alexandrium species, and occur in highly supported clades (Figs. 2 and 4). In particular, although sxtA4 was highly conserved, the phylogeny of sxtA4 based on the nucleotide alignment (Fig. 2) appears most similar to the species phylogeny of these taxa, with Gymnodinium catenatum as the fully supported (100/1.00) outgroup. This indicates that the gene may have evolved in a common dinoflagellate ancestor of Gymnodinium catenatum, Pyrodinium bahamense and Alexandrium spp. the radiation within the Alexandrium species occurring later, $\geqslant 77$ MYA (John et al., 2003). This would suggest that a secondary 


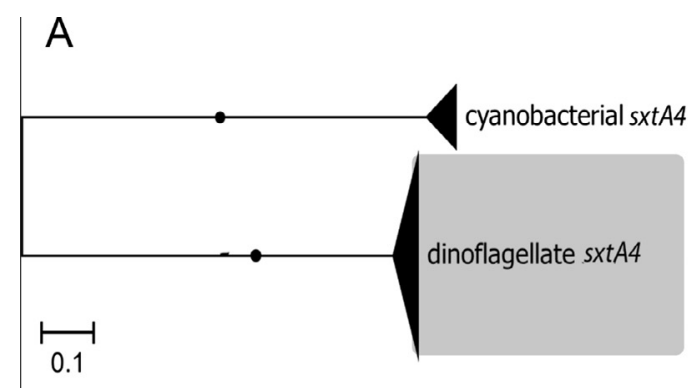

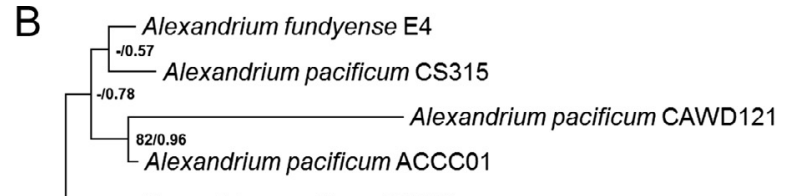

Alexandrium pacificum CCMP1493

-Alexandrium fundyense CCMP1979

Alexandrium pacificum ATTL01

${ }_{6210.81}^{-10.51}$ Alexandrium pacificum $\mathrm{HKA} 1$

Alexandrium pacificum ACPP01

- Alexandrium pacificum $\mathrm{ACSH} 02$

$93 / 1.00$

Alexandrium fundyense OF101

Alexandrium minutum ALSP02

Alexandrium pacificum $\mathrm{CS798}$

Alexandrium pacificum ACQH01

Alexandrium pacificum $\operatorname{CS} 313$

.53

Alexandrium fundyense SPE10 03

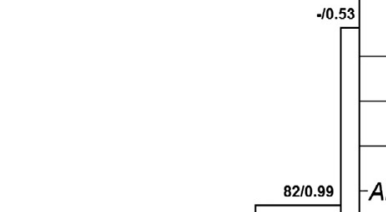

- Alexandrium fundyense $A 8$

- Alexandrium fundyense SPE10 03

- Alexandrium pacificum CS300

-Alexandrium fundyense CCMP1719

"Alexandrium tamarense CCMP1771 Group 3"

Alexandrium fundyense AtGTM253, 38-3, SPE10-03
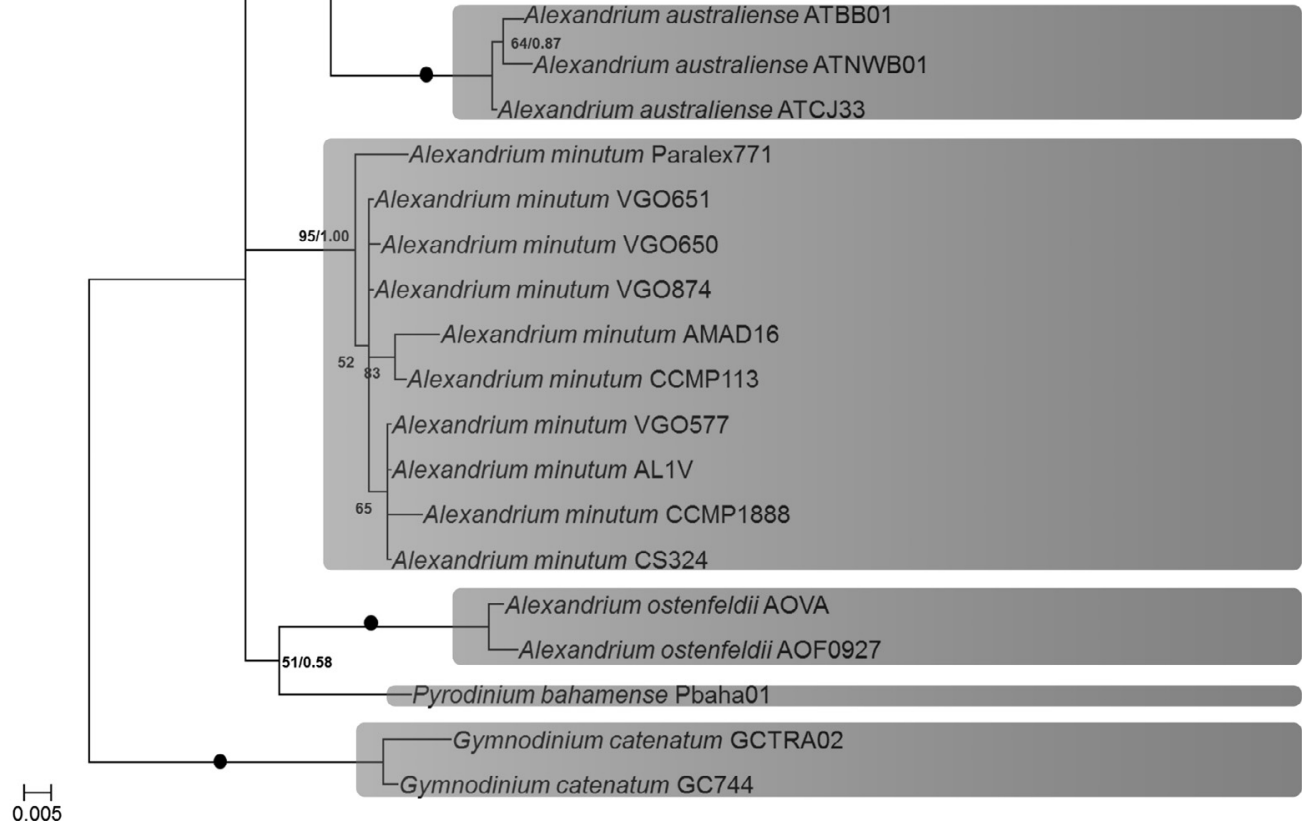

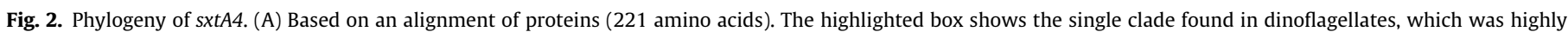

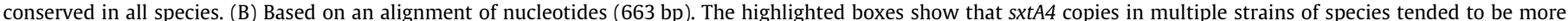

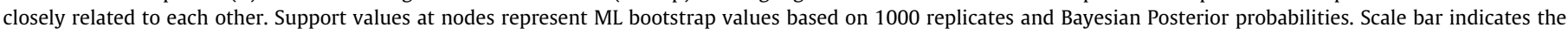
number of substitutions per site.

loss of those genes has occurred in the non-toxic Alexandrium species. The most parsimonious explanation for the origin of STX in dinoflagellates is that a single horizontal transfer event occurred early in dinoflagellate evolution. The orders Peridiniales and Gonyaulacales have an origin as far back as $\geqslant 190-180$ MYA (John et al., 2003). If the origin of these genes is this ancient, it may explain the current patchy distribution of the genes within the genome, the high number of gene duplication events in sxtA1, and the high number of paralogs and pseudogenes. Similarly, an ancient origin of the horizontal transfer of these genes from bacterial hosts may explain why multiple horizontal transfers appear to have occurred in the evolution of amidinotransferase genes and sxtG in dinoflagellates (Fig. 4).

The peculiarities of the dinoflagellate genomes might also partly explain the high number of copies of each gene within a species, and the complexity of their evolutionary histories (Lin, 2011; 


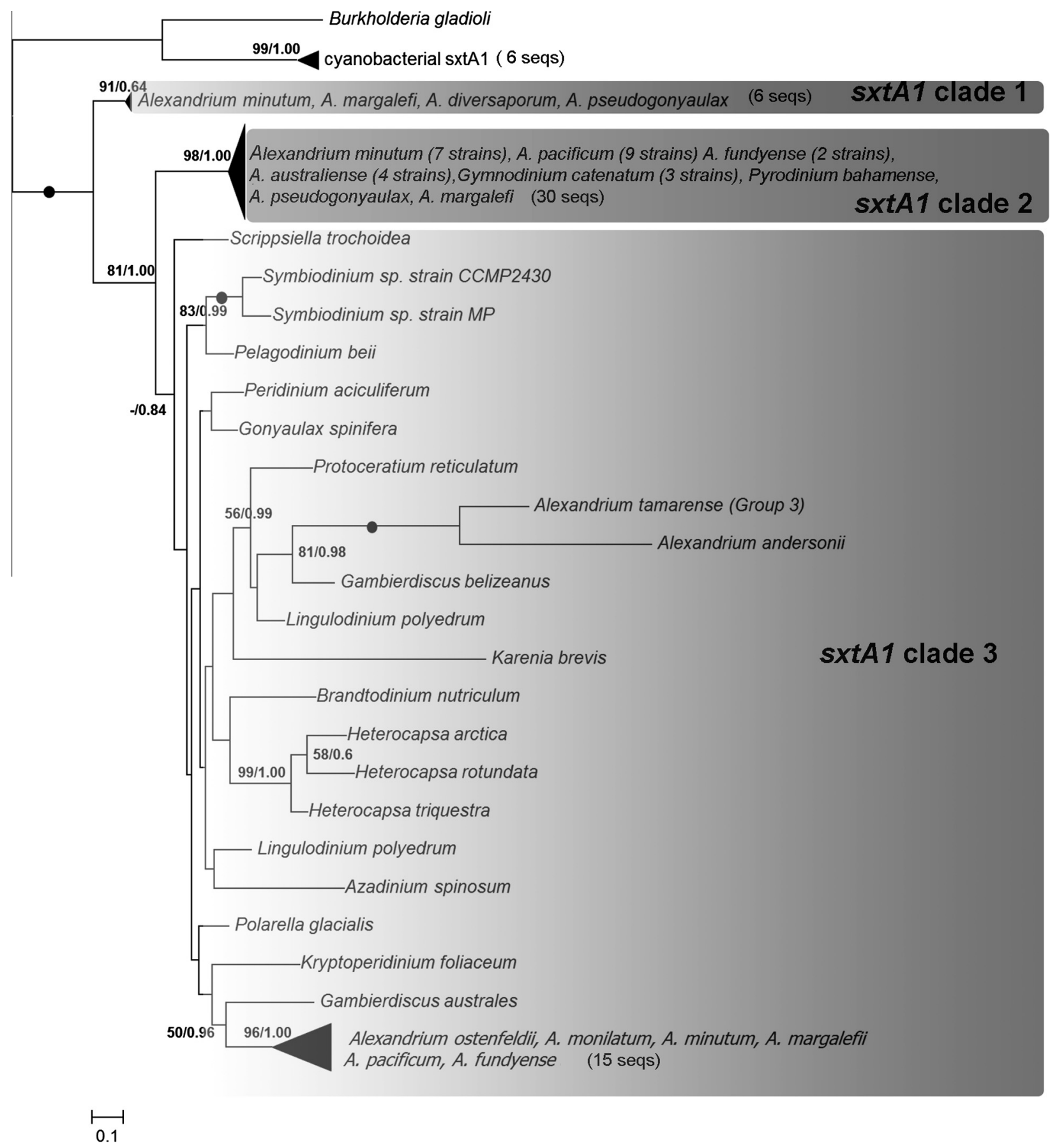

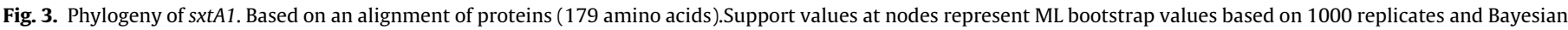
Posterior probabilities. Boxes highlighted show species. Scale bar indicates the number of substitutions per site.

Jaeckisch et al., 2011). For example, as we have shown here, gene duplication and loss appears to be very common, and genes are presented in many copies in the genome, including pseudogenes, due to processes such as the "recycling" of processed cDNAs, in which they are reverse transcribed into the genome (Zhang et al., 2007; Slamovits and Keeling, 2008). The selfish operon model (Lawrence, 1999), postulated that gene clusters encoding a particular function were likely to stay intact over time, due to common selective processes operating on their function. However, this does not appear to fit the evolution of dinoflagellate genomes. Although all genes of the sxt cluster putatively necessary for STX biosynthesis have now been found in dinoflagellates (Stüken et al., 2011;
Hackett et al., 2013), the potential signatures for an ancient horizontal gene transfer from cyanobacteria to dinoflagellates have only been detected for sxtA and sxtG so far (Stüken et al., 2011; Orr et al., 2013; Hackett et al., 2013). The other orthologs of the STX gene cluster appear to have lost their original signature over time, which was indicated by their closest sister clades being other bacterial and eukaryotic organisms, not necessarily the cyanobacterial sxt analogs, in analyses of those genes (Stüken et al., 2011; Hackett et al., 2013). The original genes may have become exchanged with other, functionally equivalent dinoflagellate genes over evolutionary time, and the genes subsequently lost. Another example in dinoflagellates in which a previously large gene cluster 


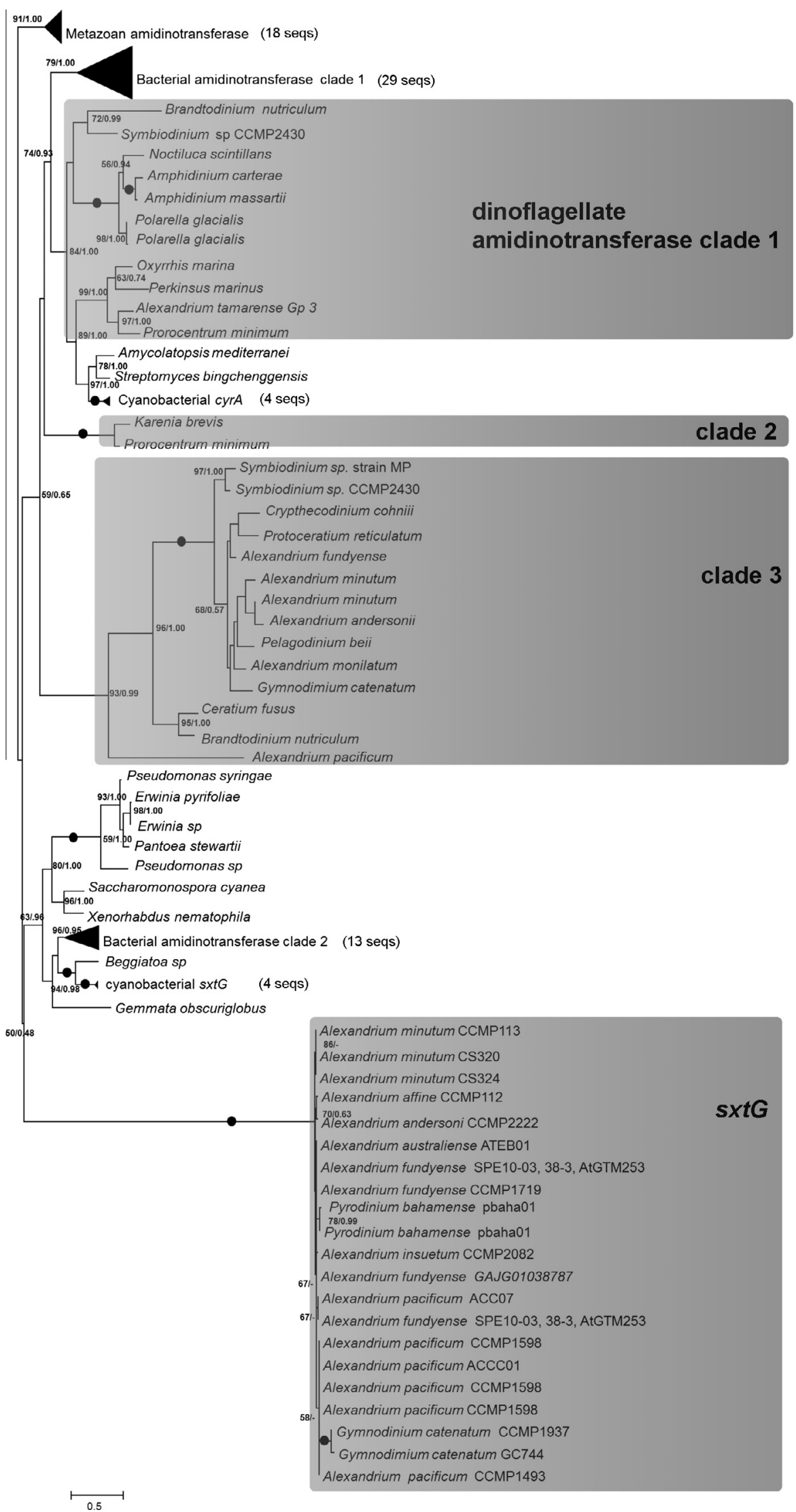

Fig. 4. Phylogeny of sxtG. Based on an alignment of proteins ( 232 amino acids).Support values at nodes represent ML bootstrap values based on 1000 replicates and Bayesian Posterior probabilities. Boxes highlighted show species. Scale bar indicates the number of substitutions per site. 
A

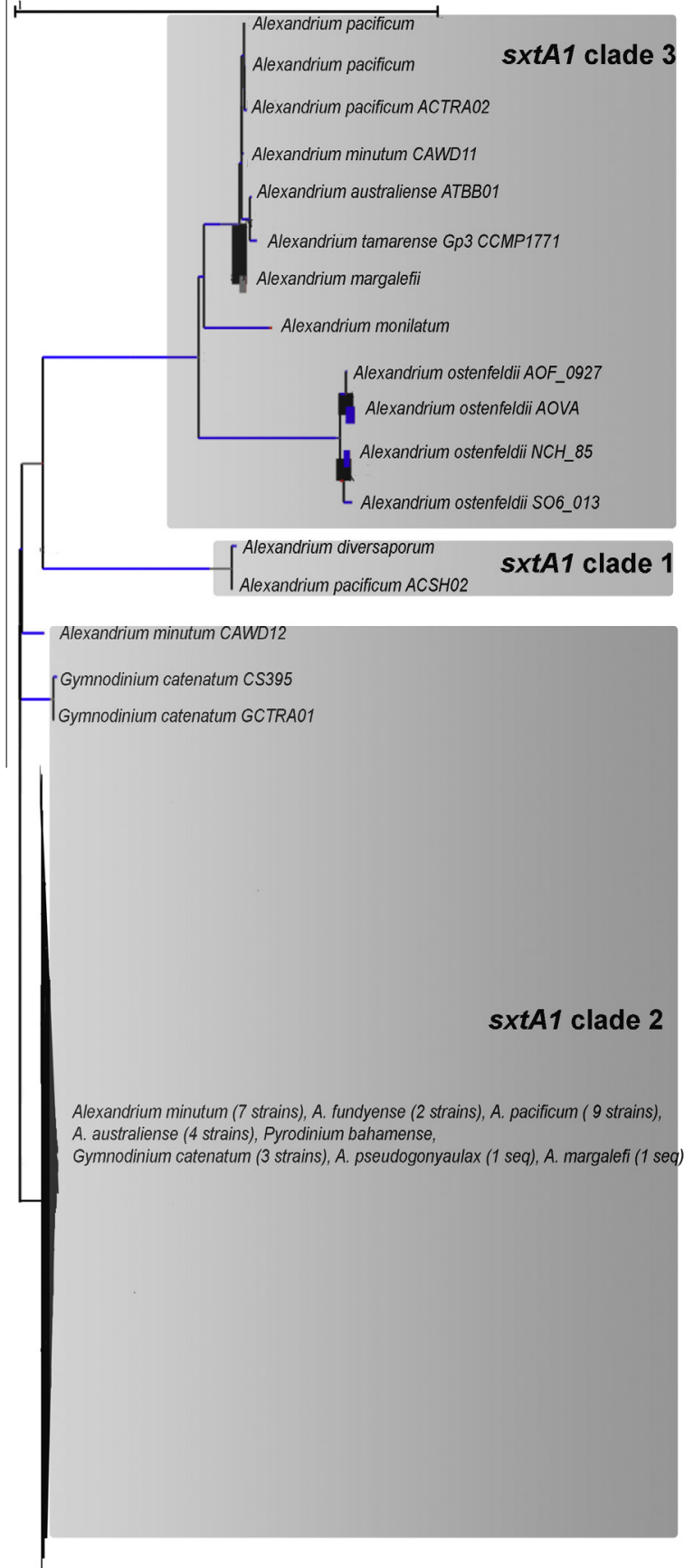

B

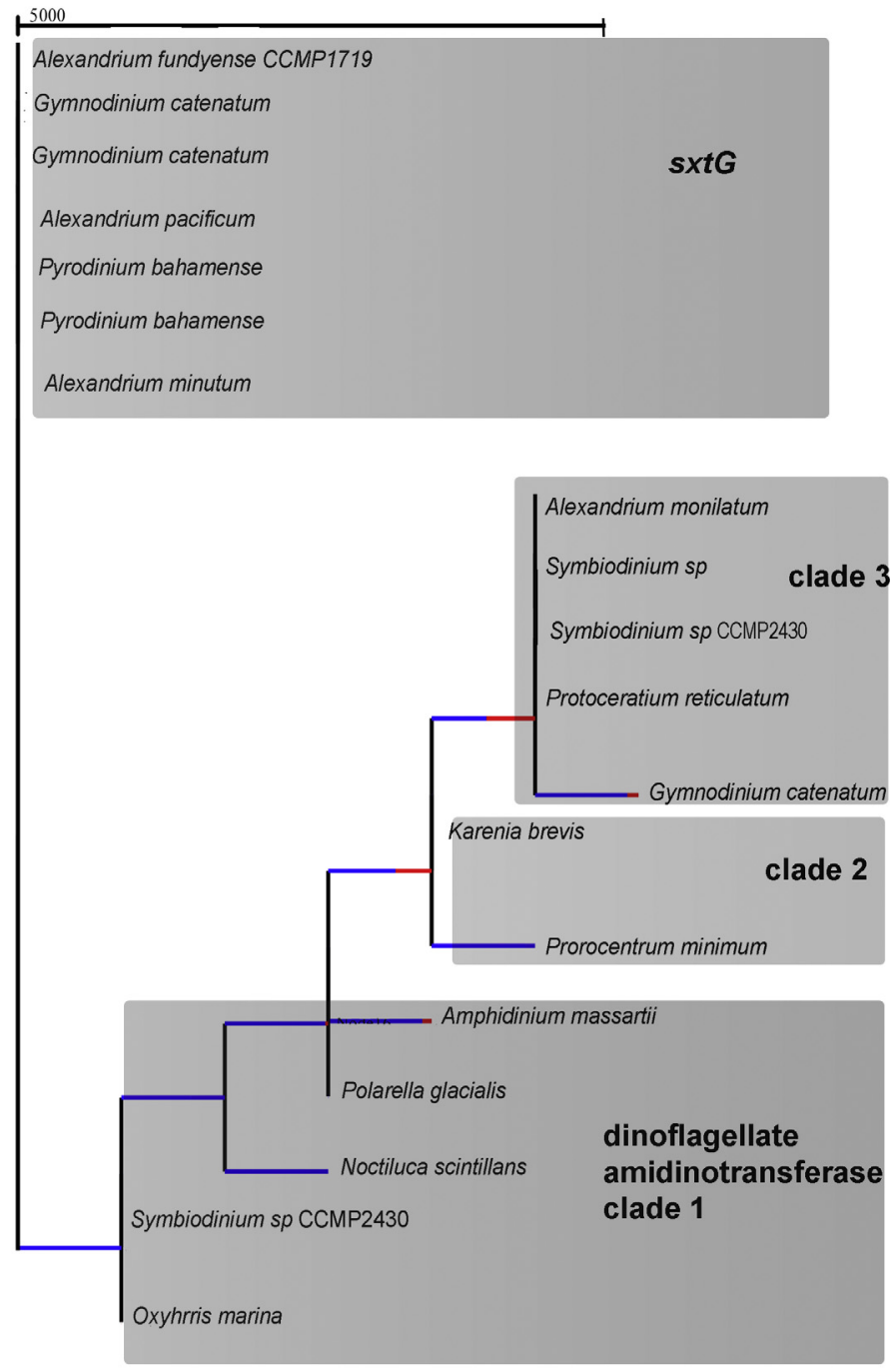

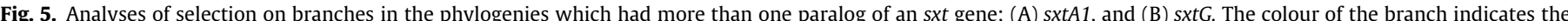

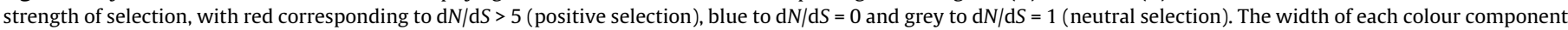

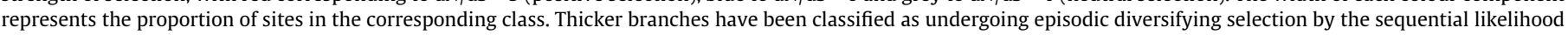
ratio test at corrected $p \leqslant 0.05$.

encoding a single multidomain enzyme has become separated into domains with many copies, rather than remaining as an operon, are polyketide synthesis (PKS) type I genes, which apparently have also experienced independent gene duplication and shuffling processes (John et al., 2008; Eichholz et al., 2012; Meyer et al., 2015).

\subsection{Selection analyses of $s x t G$ and sxtA1}

In order to better understand the evolutionary constraints responsible for the demonstrated tree topologies, we examined the potential selective forces operating on the different clades.
The two gene families for which more than one paralog was identified in dinoflagellates, $s x t A 1$ and $s x t G$, were examined to determine the role of selection following gene duplication, in the case of sxtA1, or following potential different horizontal transfer events, using the branch-site REL method. The aim of this method was to identify which lineages in the phylogenies had a proportion of sites that evolved with $\mathrm{d} N / \mathrm{d} S$ significantly greater than 1 , which would indicate instances of episodic diversifying selection at some sites in the alignment. Four branches (Fig. 5A, thick lines, $p<0.0001$ ), which represented lineages of sxtA1, clade 3, in Alexandrium ostenfeldii, and Alexandrium margalefi, showed evidence of episodic 
positive selection. The clade putatively involved in STX biosynthesis, sxtA1, clade 2 (Fig. 5A, Fig. 3), did not show branches with significant positive selection, but the branches were instead under negative (purifying) selection, indicating pressure to constrain function. In the analysis of $s x t G$, no branches showed significant episodic positive selection (Fig. 5B). The areas in the tree in which $\mathrm{d} N / \mathrm{d} S$ were highest were in dinoflagellate amidinotransferase clades 2 and 3 (Fig. 5B, red lines, indicating $\mathrm{d} N / \mathrm{d} S>5$ ). Again, the clade putatively involved in STX biosynthesis, sxtG, did not show branches with significant positive selection, but the branches were instead under negative selection, indicating functional constraint also for this gene. Therefore, for stxA1 and similarly stx $G$, we have shown the presence of several paralogs in different, well-supported clades, indicating that they may perform separate functions, and supported by instances of positive selection, which may have enhanced the development of differing functions. In contrast, those clades putatively involved in STX biosynthesis were experiencing negative selection, and therefore appeared to be functional conserved.

\section{Conclusions}

An understanding of the evolution of a marine biotoxin with major ecological impacts can yield important information on eukaryotic evolutionary processes. We have investigated the vertical and/or lateral inheritance of genes involved in STX biosynthesis in the marine dinoflagellates, in comparison to the evolution of the species producing STX. We found that gene duplication followed by loss and stronger functional constraints has played a major role in the evolution of $s x t A$, domain A1, and sxtG. The domain sxtA4, however, was highly conserved, had no paralogs, and was restricted to those species which can produce STX.

\section{Acknowledgments}

This study was funded by the Australian Research Council Grant DP120103199 to SM and UJ. This is contribution number xx from the Sydney Institute of Marine Science. Additional financial support to U.J. was provided by the PACES research program of the Alfred-Wegener-Institute Helmholtz-Zentrum für Polar- und Meeresforschung and to UJ and SM via the PT-DLR IB (Australian Academy of Science German Australian mobility call project 01DR14006). We thank the Cawthron Institute and Gustaaf Hallegraeff for the provision of cultures.

\section{Appendix A. Supplementary material}

Supplementary data associated with this article can be found, in the online version, at http://dx.doi.org/10.1016/j.ympev.2015.06. 017.

\section{References}

Abascal, F., Zardoya, R., Posada, D., 2005. ProtTest: selection of best-fit models of protein evolution. Bioinformatics 21, 2104-2105.

Alpermann, T.J., Tillmann, U., Beszteri, B., Cembella, A.D., John, U., 2010. Phenotypic variation and genotypic diversity in a planktonic population of the toxigenic marine dinoflagellate Alexandrium tamarense (Dinophyceae). J. Phycol. 46, 18-32.

Anderson, D.M., Alpermann, T.J., Cembella, A.D., Collos, Y., Masseret, E., Montresor, M., 2012. The globally distributed genus Alexandrium: multifaceted roles in marine ecosystems and impacts on human health. Harmful Algae 14, 10-35.

Bachvaroff, T.R., Place, A.R., 2008. From stop to start: tandem gene arrangement, copy number and trans-splicing sites in the dinoflagellate Amphidinium carterae. PLoS ONE 3 (8), e2929.

Balech, E., 1995. The Genus Alexandrium Halim (Dinoflagellata). Shenkin Island Press.

Band-Schmidt, C.J., Lilly, E.L., Anderson, D.M., 2003. Identification of Alexandrium affine and A. margalefi (Dinophyceae) using DNA sequencing and LSU rDNAbased RFLP-PCR assays. Phycologia 42, 261-268.
Brown, L., Bresnan, E., Graham, J., Lacaze, J.-P., Turrell, E., Collins, C., 2010. Distribution, diversity and toxin composition of the genus Alexandrium (Dinophyceae) in Scottish waters. Eur. J. Phycol. 45, 375-393.

Castresana, J., 2000. Selection of conserved blocks from multiple alignments for their use in phylogenetic analysis. Mol. Biol. Evol. 17 (4), 540-552.

Cembella, A., Destombe, C., 1996. Genetic differentiation among Alexandrium populations from eastern Canada. In: Harmful and Toxic Algal Blooms. I. O. C. UNESCO, Paris, pp. 447-450.

Ciminiello, P., Fattorusso, E., Forino, M., Montresor, M., 2000. Saxitoxin and neosaxitoxin as toxic principles of Alexandrium andersonii(Dinophyceae) from the Gulf of Naples, Italy. Toxicon 38 (12), 1871-1877.

Dantzer, W., Levin, R., 1997. Bacterial influence on the production of paralytic shellfish toxins by dinoflagellated algae. J. Appl. Microbiol. 83, 464-469.

Doblin, M.A., Blackburn, S.I., Hallegraeff, G.M., 1999. Comparative study of selenium requirements of three phytoplankton species: Gymnodinium catenatum, Alexandrium minutum (Dinophyta) and Chaetoceros cf. tenuissimus (Bacillariophyta). J. Plankton Res. 21, 1153-1169.

Eichholz, K., Beszteri, B., John, U., 2012. Putative monofunctional type I polyketide synthase units: a dinoflagellate-specific feature? PLoS ONE 7 (11), e48624.

Farrell, H., Brett, S., Ajani, P., Murray, S., 2013. Distribution of the genus Alexandrium and paralytic shellfish toxins along the coastline of New South Wales, Australia. Mar. Poll. Bull. 72, 133-145.

Fischbach, M.A., Walsh, C.T., Clardy, J., 2008. The evolution of gene collectives: how natural selection drives chemical innovation. Proc. Nat. Acad. Sci. USA 105, 4601-4608.

Frangopulos, M., Guisande, C., deBlas, E., Maneiro, I., 2004. Toxin production and competitive abilities under phosphorus limitation of Alexandrium species, Harmful Algae 3 (2), 131-139.

Hackett, J.D., Wisecaver, J.H., Brosnahan, M.L., Kulis, D.M., Anderson, D.M., Bhattacharya, D., Plumley, F.G., Erdner, D.L., 2013. Evolution of saxitoxin synthesis in cyanobacteria and dinoflagellates. Mol. Biol. Evol. 30, 70-78.

Hallegraeff, G., Bolch, C., Blackburn, S., Oshima, Y., 1991. Species of the toxigenic dinoflagellate genus Alexandrium in southeastern Australian waters. Bot. Mar. 34 (6), 575-588.

Harada, T., Oshima, Y., Yasumoto, T., 1982. Structures of two paralytic shellfish toxins, gonyautoxins $\mathrm{V}$ and $\mathrm{VI}$, isolated from a tropical dinoflagellate, Pyrodinium bahamense var. compressa. Agric. Biol. Chem. 46, 1861-1864.

Hii, K.S., Lim, P.-T., Tan, T.-H., Leaw, C.-P., 2012. Characterization of the saxitoxin biosynthetic starting gene, sxtA in the toxic dinoflagellate Alexandrium tamiyavanichi. In: The 12th Symposium of the Malaysian Society of Applied Biology: Solutions to Global Challenges and Issues. p. 196-202.

Jaeckisch, N., Yang, I., Wohlrab, S., Gloeckner, G., Kroymann, J., Vogel, H., Cembella, A., John, U., 2011. Comparative genomic and transcriptomic characterization of the toxigenic marine dinoflagellate Alexandrium ostenfeldii. PLoS ONE 6, e28012.

John, U., Fensome, R.A., Medlin, L.K., 2003. The application of a molecular clock based on molecular sequences and the fossil record to explain biogeographic distributions within the Alexandrium tamarense species complex (Dinophyceae). Mol. Biol. Evol. 20 (7), 1015-1027.

John, U., Beszteri, B., Derelle, E., Van de Peer, Y., Read, B., Moreau, H., Cembella, A.D., 2008. Novel insights into evolution of protistan polyketide synthases through phylogenomic analysis. Protist 159, 21-30.

John, U., Litaker, W., Montresor, M., Murray, S., Broshanan, M., Anderson, D., 2014 Formal revision of the Alexandrium tamarense species complex (Dinophyceae) taxonomy: The introduction of five species with emphasis on molecular-based (rDNA) classification. Protist 165, 779-804.

Iørgensen, M.F., Murray, S.A., Daugbjerg, N., 2004. Amphidinium revisited. I. Redefinition of Amphidinium (Dinophyceae) based on cladistic and molecular phylogenetic analyses. J. Phycol. 40, 351-365.

Katoh, K., Toh, H., 2008. Recent developments in the MAFFT multiple sequence alignment program. Briefings Bioinf. 9 (4), 286-298.

Kearse, M., Moir, R., Wilson, A., Stones-Havas, S., Cheung, M., Sturrock, S., Buxton, S., Cooper, A., Markowitz, S., Duran, C., Thierer, T., Ashton, B., Meintjes, P., Drummond, A., 2012. Geneious Basic: an integrated and extendable desktop software platform for the organization and analysis of sequence data. Bioinformatics 28 (12), 1647-1649.

Keeling, P.J., Palmer, J.D., 2008. Horizontal gene transfer in eukaryotic evolution. Nat. Rev. Genet. 9, 605-618.

Keller, M.D., Selvin, R.C., Claus, W., Guillard, R.R.L., 1987. Media for the culture of oceanic ultraphytoplankton. J. Phycol. 23, 633-638.

Kellmann, R., Mihali, T.K., Jeon, Y.J., Pickford, R., Pomati, F., Neilan, B., 2008. Biosynthetic intermediate analysis and functional homology reveal a saxitoxin gene cluster in cyanobacteria. Appl. Environ. Microbiol. 74, 4044-4053.

Kremp, A., Godhe, A., Egardt, J., Dupont, S., Suikkanen, S., Casabianca, S., Penna, A., 2012. Intra-specific variability in the response of bloom forming marine microalgae to changing climatic conditions. Ecol. Evol. 2, 1195-1207.

Kremp, A., Tahvanainen, P., Litaker, W., Krock, B., Suikkanen, S., Leaw, C.-P., Tomas, C., 2014. Phylogenetic relationships, morphological variation and toxin patterns in the Alexandrium ostenfeldii (Dinophyceae) complex: implications for species boundaries and identities. J. Phycol. 50, 81-100.

Lartillot, N., Lepage, T., Blanquart, S., 2009. PhyloBayes 3: a Bayesian software package for phylogenetic reconstruction and molecular dating. Bioinf. App. Note 25 (17), 2286-2288.

Lawrence, J., 1999. Selfish operons: the evolutionary impact of gene clustering in prokaryotes and eukaryotes. Curr. Opinion Genet. Dev. 9, 642-648. 
Le, Q.H., Markovic, P., Hastings, J.W., Jovine, R.V., Morse, D., 1997. Structure and organization of the peridinin chlorophyll a-binding protein gene in Gonyaulax polyedra. Mol. Gen. Genet. 255, 595-604.

Leaw, C.P., Lim, P.T., Ng, B.K., Cheah, M.Y., Ahmad, A., Usup, G., 2005. Phylogenetic analysis of Alexandrium species and Pyrodinium bahamense (Dinophyceae) based on theca morphology and nuclear ribosomal gene sequence. J. Phycol. 44 (5), 550-565.

Lim, P.-T., Ogata, T., 2005. Salinity effect on growth and toxin production of four tropical Alexandrium species (Dinophyceae). Toxicon 45, 699-710.

Lin, S., 2011. Genomic understanding of dinoflagellates. Res. Microbiol. 166, 551569.

Llewellyn, L., Negri, A., Robertson, A., 2006. Paralytic shellfish toxins in tropical oceans. Toxin Rev. 25, 159-196.

MacKenzie, L., Berkett, N., 1997. Cell morphology and PSP-toxin profiles of Alexandrium minutum in the Marlborough Sounds, New Zealand. N. Z. J. Mar. Freshwat. Res. 31, 403-409.

MacKenzie, L., de Salas, M., Adamson, J., Beuzenberg, V., 2004. The dinoflagellate genus Alexandrium (Halim) in New Zealand coastal waters: comparative morphology, toxicity and molecular genetics. Harmful Algae 3 (1), 71-92.

Maddison, W.P., Maddison, D.R., 2011. Mesquite: a Modular System for Evolutionary Analysis. Version 2.75. 2011. URL <http://mesquiteproject.org>.

Marchler-Bauer, A., Lu, S., Anderson, J.B., Chitsaz, F., Derbyshire, M.K., DeWeeseScott, C., Fong, J.H., Geer, L.Y., Geer, R.C., Gonzales, N.R., Gwadz, M., Hurwitz, D.I., Jackson, J.D., Ke, Z., Lanczycki, C.J., Lu, F., Marchler, G.H., Mullokandov, M., Omelchenko, M.V., Robertson, C.L., Song, J.S., Thanki, N., Yamashita, R.A., Zhang, D., Zhang, N., Zheng, C., Bryant, S.H., 2011. CDD: a conserved domain database for the functional annotation of proteins. Nucleic Acids Res. 39 (Suppl. 1), D225-D229.

Medlin, L., Elwood, H.J., Stickel, S., Sogin, M.L., 1988. The characterization of enzymatically amplified eukaryotic 16S-like rRNA-coding regions. Gene 71 (2), 491-499.

Meyer, J.M., Rödelsberger, C., Eichholz, K., Tillmann, U., Cembella, A., McGaughran, A., John, U., 2015. Transcriptomic characterisation and genomic glimpse into the toxigenic dinoflagellate Azadinium spinosum with emphasis on polyketide synthase genes. BMC Genom. http://dx.doi.org/10.1186/s12864-014-1205-6.

Mihali, T.K., Kellmann, R., Neilan, B.A., 2009. Characterisation of the paralytic shellfish toxin biosynthesis gene clusters in Anabaena circinalis AWQC131C and Aphanizomenon sp. NH-5. BMC Biochem. 10, 8.

Mihali, T.K., Carmichael, W.W., Neilan, B.A., 2011. A putative gene cluster from a Lyngbya wollei bloom that encodes paralytic shellfish toxin biosynthesis. PLoS ONE 6, e14657.

Moustafa, A., Loram, J.E., Hackett, J.D., Anderson, D.M., Plumley, F.G., 2009. Origin of saxitoxin biosynthetic genes in cyanobacteria. PLoS ONE 4, e5758.

Murray, S.A., Flø Jørgensen, M., Ho, S.Y., Patterson, D.J., Jermiin, L.S., 2005. Improving the analysis of dinoflagellate phylogeny based on rDNA. Protist 156, 269-286.

Murray, S.A., Wiese, M., Stüken, A., Brett, S., Kellmann, R., Hallegraeff, G.M., Neilan, B.A., 2011a. SxtA-based quantitative molecular assay to identify saxitoxinproducing harmful algal blooms in marine waters. Appl. Environ. Microbiol. 77, 7050-7057.

Murray, S.A., Mihali, T.K., Neilan, B.A., 2011b. Extraordinary conservation, gene loss, and positive selection in the evolution of an ancient neurotoxin. Mol. Biol. Evol. 28, 1173-1182.

Murray, S.A., Garby, T., Hoppenrath, M., Neilan, B.A., 2012a. Genetic diversity, morphological uniformity and polyketide production in dinoflagellates (Amphidinium, Dinoflagellata). PLoS ONE 7 (6), e38253.

Murray, S.A., Wiese, M., Brett, S., Orr, R., Neilan, B.A., Hallegraeff, G., 2012b. A reinvestigation of saxitoxin production and sxtA in the 'non-toxic' Alexandrium tamarense Group V clade. Harmful Algae 18, 96-104.

Murray, S.A., Hoppenrath, M., Orr, R.J.S., Bolch, C., John, U., Diwan, R., Yauwenas, R., Harwood, T., de Salas, M., Neilan, B., Hallegraeff, G., 2014. Alexandrium diversaporum sp. nov., a new non-saxitoxin producing species: Phylogeny, morphology, and sxtA genes. Harmful Algae 31, 54-65.

Murray, S.A., John, U., Kremp, A., 2015. Alexandrium spp: genetic and ecological factors influencing saxitoxin production and proliferation. In: Botana, L.M., Louzao, M.C., Vilarino, N. (Eds.), Climate Change and Marine and Freshwater Toxins. DE Gruyter, Berlin, pp. 123-139.

Negri, A., Llewellyn, L., Doyle, J., Webster, N., Frampton, D., Blackburn, S., 2003. Paralytic shellfish toxins are restricted to few species among Australia‘s taxonomic diversity of cultured microalgae. J. Phycol. 39 (4), 663-667.

Nguyen Ngoc, L., 2004. An autecological study of the potentially toxic dinoflagellate Alexandrium affine isolated from Vietnamese waters. Harmful Algae 3, 117-129.

Orr, R.J.S., Stüken, A., Rundberget, T., Eikrem, W., Jakobsen, K.S., 2011. Improved phylogenetic resolution of toxic and non-toxic Alexandrium strains using a concatenated rDNA approach. Harmful Algae 10 (6), 676-688.

Orr, R.J.S., Murray, S., Stüken, A., Rhodes, L., Jakobsen, K.S., 2012. When naked became armored: an eight-gene phylogeny reveals monophyletic origin of theca in dinoflagellates. PLoS ONE 7 (11), e50004.

Orr, R.J.S., Stüken, A., Murray, S., Jakobsen, K.S., 2013. Evolutionary acquisition and loss of saxitoxin biosynthesis in Dinoflagellates: lessons from the second "core" gene - sxtG. Appl. Environ. Microbiol. 79, 2128-2136.
Oshima, Y., Hasegawa, M., Yasumoto, T., Hallegraeff, G., Blackburn, S., 1987. Dinoflagellate Gymnodinium catenatum as the source of paralytic shellfish toxins in Tasmanian shellfish. Toxicon 25, 1105-1111.

Parkhill, J.-P., Cembella, A.D., 1999. Effects of salinity, light and inorganic nitrogen on growth and toxigenicity of the marine dinoflagellate Alexandrium tamarense from northeastern Canada. J. Plankton Res. 21, 939-955.

Perini, F., Galluzzi, L., Dell'Aversano, C., Iacovo, E.D., Tartaglione, L., Ricci, F., Forino, M., Ciminiello, P., Penna, A., 2014. SxtA and sxtG gene expression and toxin production in the Mediterranean Alexandrium minutum (Dinophyceae). Mar Drugs 12 (10), 5258-5276.

Pond, S.L.K., Murrell, B., Fourment, M., Frost, S.D., Delport, W., Scheffler, K., 2011. A random effects branch-site model for detecting episodic diversifying selection. Mol. Biol. Evol. 28 (11), 3033-3043.

Rogers, J.E., Leblond, J.D., Moncreiff, C.A., 2006. Phylogenetic relationship of Alexandrium monilatum (Dinophyceae) to other Alexandrium species based on 18S ribosomal RNA gene sequences. Harmful Algae 5 (3), 275-280.

Sampedro, N., Franco, J.M., Zapata, M., Riobó, P., Garcés, E., Penna, A., Caillaud, A.. Diogène, J., Cacho, E., Camp, J., 2013. The toxicity and intraspecific variability of Alexandrium andersonii Balech. Harmful Algae 25, 26-38.

Scholin, C.A., Herzog, M., Sogin, M., Anderson, D.M., 1994. Identification of group and strain specific genetic markers for globally distributed Alexandrium (Dinophyceae). II Sequence analysis of a fragment of the LSU rRNA gene. J. Phycol. 30 (6), 999-1011.

Selander, E., Thor, P., Toth, G., Pavia, H., 2006. Copepods induce paralytic shellfish toxin production in marine dinoflagellates. Proc. R. Soc. London B 273, $1673-$ 1680.

Shalchian-Tabrizi, K., Minge, M.A., Cavalier-Smith, T., Nedreklepp, J.M., Klaveness, D., 2006. Combined heat shock protein 90 and ribosomal RNA sequence phylogeny supports multiple replacements of dinoflagellate plastids. J. Euk. Microb. 53, 217-224.

Slamovits, C.H., Keeling, P.J., 2008. Widespread recycling of processed cDNAs in dinoflagellates. Curr. Biol. 18 (13), R550-R552.

Stamatakis, A., 2006. RAxML-VI-HPC: maximum likelihood-based phylogenetic analyses with thousands of taxa and mixed models. Bioinformatics 22 (21), 2688.

Stucken, K., John, U., Cembella, A., Murillo, A.A., Soto-Liebe, K., 2010. The smallest known genomes of multicellular and toxic cyanobacteria: comparison, minimal gene sets for linked traits and the evolutionary implications. PLoS ONE 5, e9235.

Stüken, A., Orr, R.J.S., Kellmann, R., Murray, S.A., Neilan, B.A., Jakobsen, K.S., 2011 Discovery of nuclear-encoded genes for the neurotoxin saxitoxin in dinoflagellates. PLoS ONE 6 (5), e20096.

Suikkanen, S., Kremp, A., Hautala, H., Krock, B., 2013. Effects of salinity on growth rate and PST/spirolide production of the dinoflagellate Alexandrium ostenfeldii. Harmful Algae 26, 52-59.

Touzet, N., Franco, J.M., Raine, R., 2007. Characterization of nontoxic and toxin producing strains of Alexandrium minutum (Dinophyceae) in Irish coastal waters. Appl. Environ. Microbiol. 73 (10), 3333-3342.

Touzet, N., Franco, J.M., Raine, R., 2008. Morphogenetic diversity and biotoxin composition of Alexandrium (Dinophyceae) in Irish coastal waters. Harmful Algae 7, 782-797.

Van de Waal, D.B., Smith., V.H., Declerck, S.A.J., Stam, E.C.M., Elser, J.J., 2014 Stoichiometric regulation of phytoplankton toxins. Ecol. Lett., 1-7

Waller, R.F., Slamovits, C.H., Keeling, P.J., 2006. Lateral gene transfer of a multigene region from cyanobacteria to dinoflagellates resulting in a novel plastidtargeted fusion protein. Mol. Biol. Evol. 23 (7), 1437-1443.

Wang, D.-Z., Zhang, S.G., Gu, H.-F., Chan, L.L., Hong, H.-S., 2006. Paralytic shellfish toxin profiles and toxin variability of the genus Alexandrium (Dinophyceae) isolated from the Southeast China Sea. Toxicon 48, 138-151.

Wiens, J.J., 2005. Can incomplete taxa rescue phylogenetic analyses from longbranch attraction? Syst. Biol. 54, 731-742.

Wiese, M., 2012. Investigations into Abiotic and Biotic Factors Regulating Saxitoxin Synthesis in the Dinoflagellate Genus Alexandrium. PhD thesis, University of New South Wales, Australia.

Wisecaver, J., Hackett, J., 2014. The impact of automated filtering of BLASTdetermined homologs in the phylogenetic detection of horizontal gene transfer from a transcriptome assembly. Mol. Phylogenet. Evol. 71, 184-192.

Wohlrab, S., Iversen, M., John, U., 2010. A molecular and co-evolutionary context for grazer induced toxin production in Alexandrium tamarense. PLoS ONE 5 (11) e15039.

Yang, I., John, U., Beszteri, S., Glockner, G., Krock, B., Goesmann, A., Cembella, A.D., 2010. Comparative gene expression in toxic versus non-toxic strains of the marine dinoflagellate Alexandrium minutum. BMC Genom. 11, 248.

Yang, I., Selander, E., Pavia, H., John, U., 2011. Grazer-induced toxin formation in dinoflagellates: a transcriptomic model study. Eur. J. Phycol. 46 (1), 66-73.

Zhang, H., Hou, Y., Miranda, L., Campbell, D.A., Sturm, N.R., Gaasterland, T., Lin, S. 2007. Spliced leader RNA trans-splicing in dinoflagellates. Proc. Nat. Acad. Sci. USA 104, 4618-4623.

Zhang, Y., Zhang, S.F., Lin, L., Wang, D.Z., 2014. Comparative transcriptome analysis of a toxin-producing dinoflagellate Alexandrium catenella and its non-toxic mutant. Mar. Drugs 12, 5698-5718. 